University of Nebraska - Lincoln

DigitalCommons@University of Nebraska - Lincoln

Publications from USDA-ARS / UNL Faculty

U.S. Department of Agriculture: Agricultural

Research Service, Lincoln, Nebraska

2008

Salt Cedar Areawide Pest Management in the Western USA

Raymond I. Carruthers

USDA-ARS, ray.carruthers@ars.usda.gov

C. Jack DeLoach

USDA-ARS

John C. Herr

USDA-ARS, john.herr@ars.usda.gov

Gerald L. Anderson

USDA-ARS

Allen E. Knutson

Texas A\&M University, a-knutson@tamu.edu

Follow this and additional works at: https://digitalcommons.unl.edu/usdaarsfacpub

Part of the Agricultural Science Commons

Carruthers, Raymond I.; DeLoach, C. Jack; Herr, John C.; Anderson, Gerald L.; and Knutson, Allen E., "Salt Cedar Areawide Pest Management in the Western USA" (2008). Publications from USDA-ARS / UNL Faculty. 655.

https://digitalcommons.unl.edu/usdaarsfacpub/655

This Article is brought to you for free and open access by the U.S. Department of Agriculture: Agricultural Research Service, Lincoln, Nebraska at DigitalCommons@University of Nebraska - Lincoln. It has been accepted for inclusion in Publications from USDA-ARS / UNL Faculty by an authorized administrator of DigitalCommons@University of Nebraska - Lincoln. 


\title{
Salt Cedar Areawide Pest Management in the Western USA
}

\author{
RAYMOND I. CARRUTHERS, ${ }^{1}$ C. JACK DELOACH, ${ }^{2}$ \\ JOHN C. HERR, ${ }^{1}$ GERALD L. ANDERSON ${ }^{3}$ AND \\ ALLEN E. KNUTSON ${ }^{4}$ \\ ${ }^{1}$ USDA-ARS, Western Regional Research Center, Albany, California, \\ USA \\ ${ }^{2}$ USDA-ARS, Grassland, Soil and Water Research Laboratory, Temple, \\ Texas, USA \\ ${ }^{3}$ USDA-ARS, Northern Plains Agricultural Research Center, Sidney, \\ Montana, USA \\ ${ }^{4}$ Texas A\&M University and Texas Agricultural Experiment Station, \\ Dallas, Texas, USA
}

\section{Introduction: Description of the Problem and Need for an Areawide Pest Management Approach}

Salt cedar (Tamarix spp. (Tamaricaceae: Tamaricales)) is a group of exotic shrubs to small trees that have invaded many riparian areas and lake shores across western North America. Of the 54 species known worldwide (Baum, 1967, 1968), ten species of salt cedars have been introduced into the USA (Crins, 1989), primarily from their countries of origin across Europe and Central Asia. They are also native in Africa and the Indian subcontinent of Asia. No species from the entire family Tamaricaceae are native to North America, and only a restricted group of six species of more distantly related plants (Frankenia: Frankeniaceae) in the entire Order Tamaricales are known to exist in the USA.

Introduction of salt cedars began in the early to mid-1800s (first noted in 1823), when these species were used extensively for wind and water erosion control along railroads and waterways. Such use continued well into the mid- to late 1900s through plantings supported by federal, state and local governments and private land owners/managers. In many areas where they were planted salt cedars naturalized, became well established and spread throughout riparian areas of the west. It is now estimated that these exotic invasive shrubs infest more than 800,000 ha of highly valued riparian land from the central Great Plains to the Pacific coast, and from northern Mexico to the Canadian border.

This article is a U.S. government work, and is not subject to copyright in the United States. 
Recent DNA studies (Gaskin and Schaal, 2003) indicate that T. ramosissima Ledeb. and T. chinensis Lour. and their hybrids are the most widespread and damaging species in the western USA, along with T. parviflora D.C. in California and Nevada, and T. canariensis Willd. (and hybrids) in some south-western areas of the country, especially along the Gulf Coast of Texas and Louisiana. They are all deciduous, deep-rooted, woody shrubs to small trees, which bloom in the spring and/or summer with pink to whitish flowers and are vegetated with foliage of juniper (cedar)-like bracts (see Plate 1).

Salt cedars have many characteristics that enable them to invade and occupy riparian areas and adjacent upland sites. They produce copious amounts of small windblown or waterborne seed throughout the spring and summer seasons at times when competing native plants are not typically reproductive. They also reproduce vegetatively, which helps them spread and re-establish following floods that periodically scour western waterways (Everitt, 1980). Salt cedars are deep-rooted, facultative phreatophytes that can use groundwater, soil moisture or surface waters. Thus, once established, they can occupy areas further from the stream banks and may consume more water across a flood plain than shallow-rooted native phreatophytes (Smith et al., 1998). Salt cedars further have the advantage of being facultative halophytes that can use saline groundwater by excreting excess salts through leaf glands. This excretion results in increased salt levels in adjacent soils that may be highly limiting for other, less salt-tolerant, plant species. The resulting high soil salinity inhibits many native competitors and often leads to extensive monocultures of salt cedar (see Plate la, b).

Salt cedars are also tolerant of fire, drought, inundation, livestock or wildlife browsing (although herbivory is quite limited in North America), and thus have reproduced and spread widely with few natural controls. North American native insects and other wildlife did not evolve with salt cedar and thus rarely use it as a food resource, except that many pollinating adult insects (most produced as immatures on nearby native plants) visit salt cedar flowers for pollen and nectar (DeLoach and Tracy, 1997; DeLoach et al., 2000).

Since native insects do not feed on the vegetation, roots, boles, flowers or seeds of salt cedar, they exert no noticeable level of natural control. Salt cedars are further tolerant to mechanical damage, and readily resprout from underground lateral buds after heavy scouring or other above-ground physical injury. The lack of herbivory, coupled with salt cedar's innate ability to withstand adversity and regrow under harsh conditions, has further led to its high densities and an expanding range over the past few decades.

In addition, salt cedars also interact synergistically with human-induced ecosystem changes in ways that further increase their competitive advantages over native and other beneficial plants (DeLoach, 1991; DeLoach et al., 2000). Most significantly, changes in the timing of water flow through damming of streams in the spring and release of water in the summer, have decreased synchrony of spring-seeding native plants such as willows and cottonwoods, and have benefited summer-seeding salt cedars.

\section{Significance of the Pest Management Problem}

The invasion of riparian ecosystems by exotic salt cedars has caused one of the worst ecological disasters in the history of the western USA (Brown et al., 1989; Lovich and DeGouvenain, 1998). Salt cedars displace native riparian plant communities, degrade 
wildlife habitats (including that of many declining or endangered species), use great quantities of scarce groundwater, increase soil salinity and wildfire frequency, and interfere with recreational usage of natural areas. These invasive shrubs increase bank aggradation, narrow and deepen stream channels and alter water temperature and quality. Salt cedars damage the habitat of many aquatic invertebrates, fish and riparian animals by eliminating backwaters and open sand and gravel bars, and by changing riffle and bank structure. They often create an impenetrable thicket that can exclude large wildlife and livestock from scarce water resources in arid grazing areas. The negative aspects of the salt cedar invasion have alarmed many ecologists and environmentalists (Sala et al., 1996; Smith et al., 1998; Shaforth et al., 2005), water users, ranchers, park and wildlife managers and recreationalists, who are now requesting and/or demanding its control.

Salt cedar also has some limited beneficial value, mostly for controlling streambank erosion (for which it was originally introduced), to a lesser degree as an ornamental shrub and, occasionally, as a maintenance plant for honeybees in some locations. A few birds, including the endangered south-western subspecies of the willow flycatcher (Empidonax trailii Audubon extimus Phillips), the white-winged dove (Zenaida asiatica (L.)) and other miscellaneous animals use it for cover, as nesting sites and may feed on the pollinating insects found on its flowers. Despite these limited benefits, the USDI Fish and Wildlife Service (FWS) and other environmentally oriented groups have become aware of the damage caused by salt cedar, and now support the AWPM of this exotic plant through use of biological control and other integrated practices.

This was not always the case, but in-depth risk analyses (DeLoach, 1991; DeLoach and Tracy, 1997; DeLoach et al., 2000), including environmental and economic analyses (Brown et al., 1989; Zavaleta, 2000) have demonstrated that the damage caused by salt cedar far outweighs its few beneficial attributes, and thus helped alter the minds of conservation-oriented natural resource managers. It is now well accepted that salt cedars often competitively displace native plant communities, degrade wildlife habitat and contribute to the population decline of many species of birds, fishes, mammals and reptiles, including some 40 threatened or endangered species (see DeLoach and Tracy, 1997).

Most recently, the critical nature of the drought in the south-western USA has threatened the water supplies of municipalities and of irrigated agriculture, and caused default of water agreements between states and of the water treaty between the USA and Mexico. Salt cedar thickets typically use 4-5 acre feet of water per year, that in the present drought severely reduces the water available for agricultural irrigation, and municipal and environmental use. This has further engendered more political and monetary support for AWPM of salt cedar, using biological control as the central technology for controlling existing infestations and limiting spread of this invasive shrub.

\section{Description of Current Management Systems and Approaches}

In the absence of insect natural enemies and disease-causing organisms, salt cedar grows very aggressively and is highly competitive with native vegetation, especially in 
areas where the natural hydrology has been altered in ways that limit stream flow during spring months when native cottonwoods and willows are naturally seeding. Therefore, many of the nation's most productive and diverse ecological regions are being negatively affected by the invasion of this exotic invasive plant. Local, state and federal land and waterway managers have been fighting salt cedar in an expensive and losing battle using one or more traditional tools, such as the broadcast application of chemical herbicides, burning, physical removal via hand-cutting and stump treatment, or by bulldozing areas to remove both above and below ground salt cedar biomass.

Each of these methods has its strong and weak points but, overall, these treatments are extremely expensive, difficult to implement in wildlands or riparian areas and are highly disruptive to non-target flora and fauna in and around the affected habitats. Furthermore, extensive limitations exist due to state and federal regulations on both chemical and physical control methods in or adjacent to sensitive waterways. When used in an integrated manner, however, and linked with both areawide know-how and appropriate revegetation technology, these control methods can be effective and economical in many circumstances. If further linked with new biologically based methods that may be used as the keystone technology of an AWPM programme, they can become highly effective and sustainable.

The effectiveness and use of herbicides against salt cedars were reviewed by Sisneros (1991), who reported that Arsenal ${ }^{\circledR}$ (chemical name: imazapyr) used as an aerial spray alone or mixed with Rodeo ${ }^{\circledR}$ (glyphosate) to reduce costs, and Garlon ${ }^{\circledR} 4$ (chemical name: triclopyr) as a cut-stump or stem-slash treatment, all provide good control. Arsenal ${ }^{\circledR}$ is a very broad-spectrum herbicide (except for legumes), and the label lists 176 species that it controls: 55 species of grasses, including salt grass, which is a common pasture grass in saline areas where salt cedar grows, 75 broadleaf weeds, 13 vines and brambles and 34 brush and tree species, including some very valuable native plants like cottonwoods and willows (BASF, 2004).

Although these chemicals are potentially effective, both chemicals are expensive and also kill many native plants, thus these controls are unsatisfactory in most natural areas of mixed vegetation where the objective is to kill the invading weed and preserve the beneficial and native plant species.

Less disruptive methods of chemical control involve the direct application of chemicals such as Garlon ${ }^{\circledR} 4$ or Pathfinder ${ }^{\circledR}$ II (both triclopyr-based products) to the cut stumps of salt cedars, where it is absorbed into the opened cambium layer of the plant. Triclopyr is a synthetic auxin, a naturally occurring plant hormone that acts in plants to promote rapid growth and excessive cell division. Control of undesirable salt cedar from triclopyr treatments is essentially due to an auxin overdose that causes uncontrolled growth of the plant and eventual death at appropriate dosages. Both the cutting and application of the chemical to salt cedar stumps are labour intensive and thus costly. These methods, however, are much less disruptive to the background flora and fauna than broadcast application of a herbicide; however, the skeletons of cut salt cedars can cause increased fire danger if not physically removed from the treatment areas.

Fire, itself, has also been used extensively to help control salt cedar in many areas, as it is one of the few cost-effective ways of thinning extensive stands of salt cedar. The salt cedar tree typically begins regrowing within a month or so after a fire, 
1.

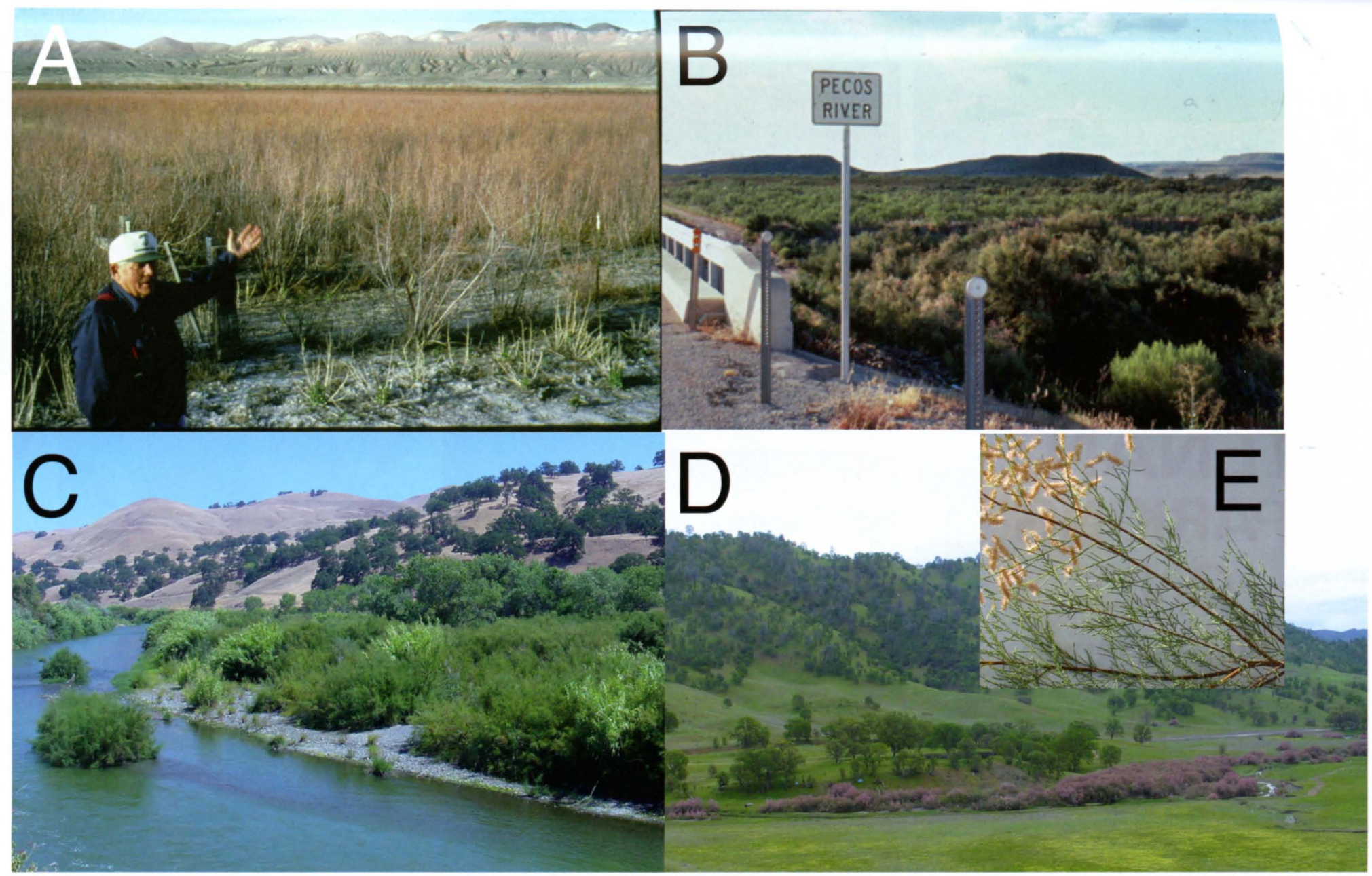

Plate 1. (A) An extensive infestation of saltcedar (Tamarix ramosissima) near Lovelock, Nevada (1997). This dormant saltcedar represents several thousand acres infested during a single flood event on the Humboldt River that spread seed nearly uniformly across the area. (B) A similar infestation of T. ramosissima along the Pecos River in Texas showing the dense foliage during the summer season. (C) Tamarix parviflora infesting Cache Creek, California, note the saltcedar growing directly in the water channel where they trap sediments, block the main channel and thus induce flooding. (D) T. parviflora in bloom along Bear Creek in California during early spring. (E) T. ramosissima blooms are variable in colour and occur throughout the summer season. 
2.
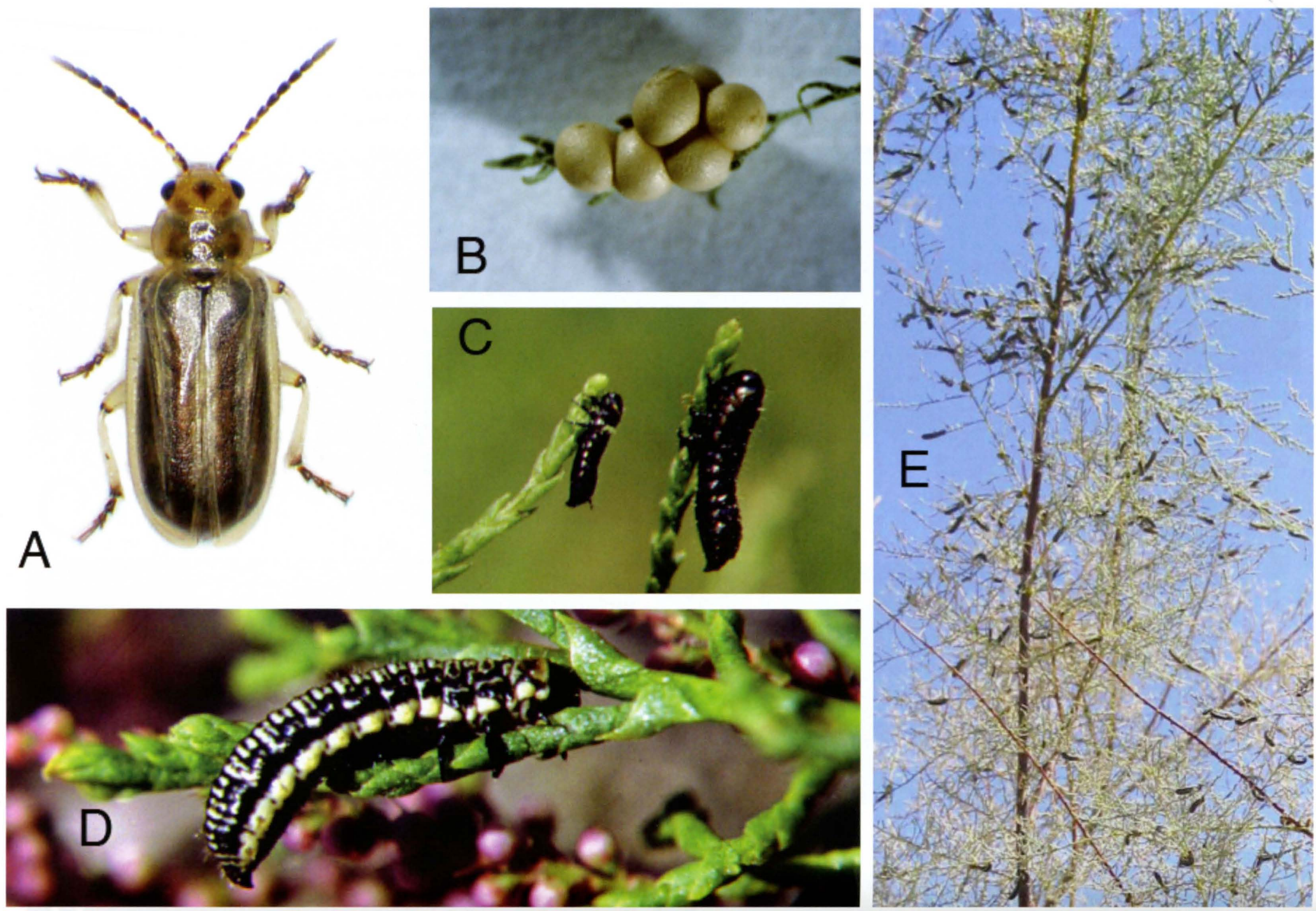

Plate 2. Life stages of Diorhabda elongata showing adults, eggs, 1st, 2nd and 3rd instars (A-D, respectively) and a common density found in the Areawide Pest Management release programmes $(E)$. 
3.

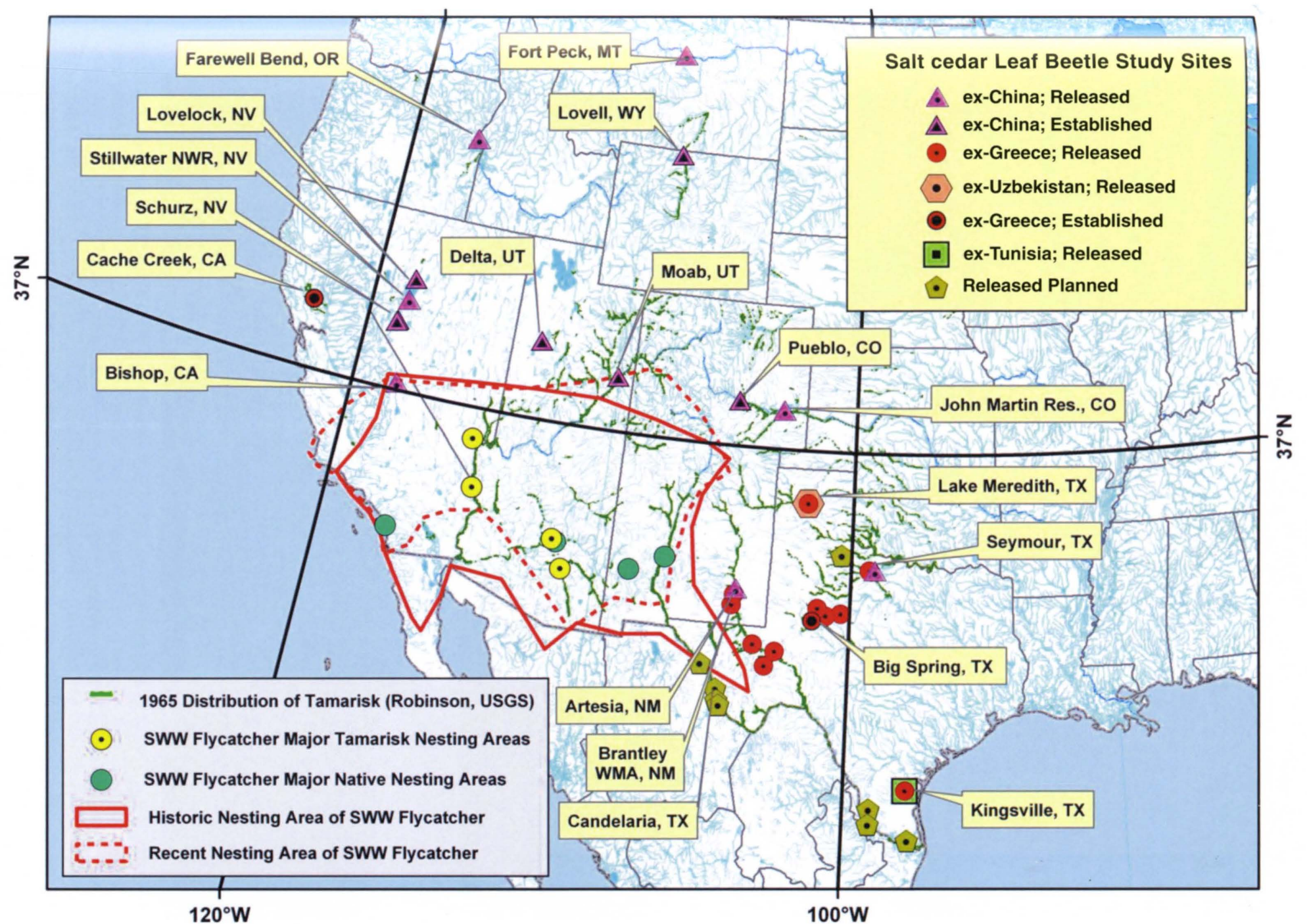

Plate 3. Study sites, including areas where the AWPM of saltcedar has been investigated. Note that Diorhabda elongata beetles from northern Asia worked best in more northern release sites and similarly $D$. elongata beetles from Greece have been released and are more effective in the southern USA. 

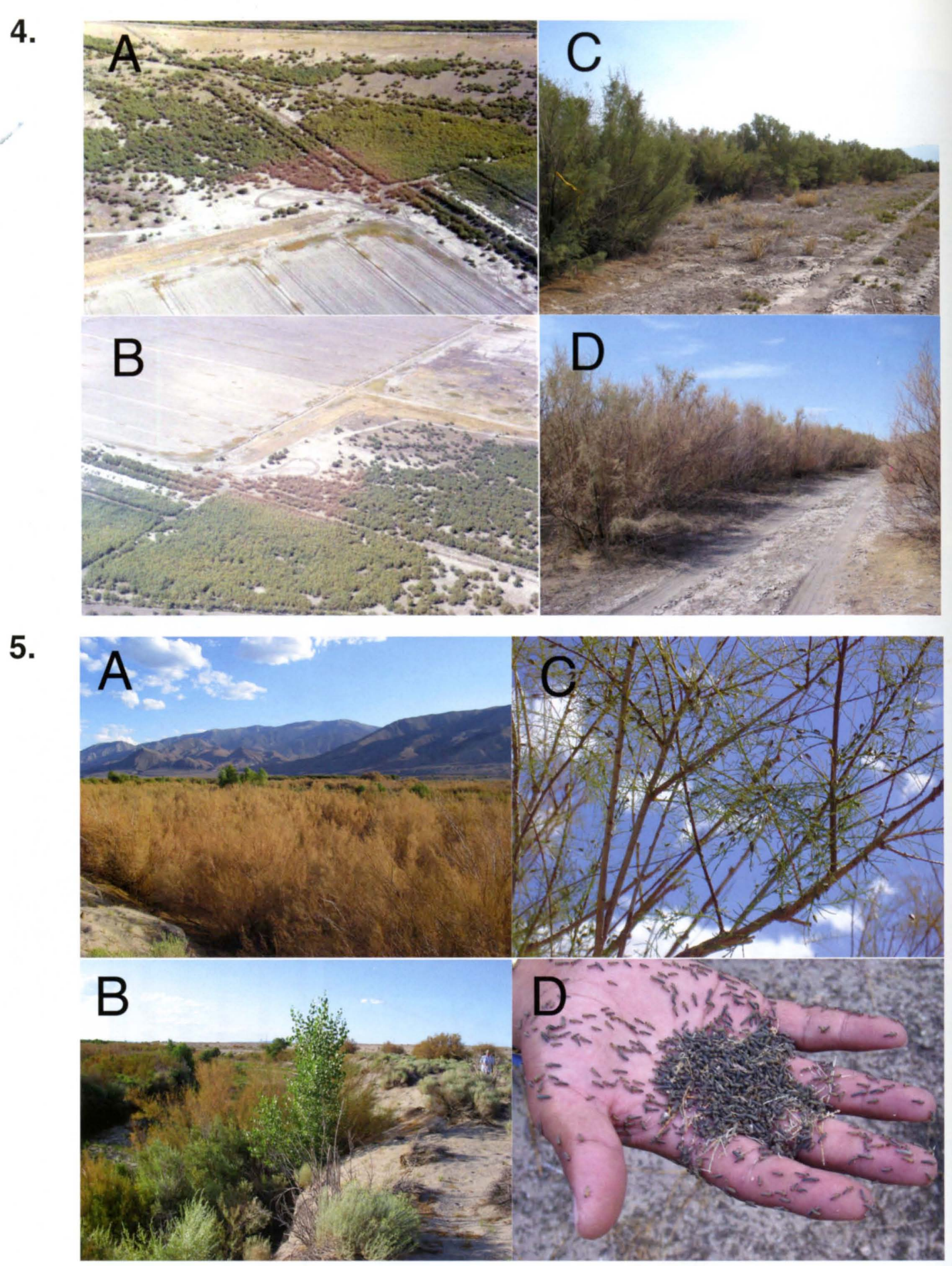

Plate 4. The centre of the Diorhabda elongata release site (area of brown vegetation) is readily evident near the looping dirt road (A and B). Outside of the release area, saltcedar plants are lush and green $(C)$, while within the release area (D) the saltcedar have been totally stripped of green foliage by $D$. elongata adults and larvae.

Plate 5. (A) Heavy first-year defoliation caused by Diorhabda elongata at the Shurz, Nevada, release site. Often, the plants dieback more severely than caused by the defoliation alone, leaving much dried leaf material on the plants. (B) Intermixed with heavily defoliated saltcedar, many native species flourish due to decreased competition from the saltcedar. No feeding has been noted on any non-target species at any of the release sites (note healthy green cottonwoods, willows, sagebrush and other species intermixed with the defoliated saltcedar (A, B)). (C) Adult $D$. elongata populations at these sites were very high. (D) Larval populations at the same sites were at tremendous levels for multiple seasons causing repeated defoliations over several seasons. 
6.
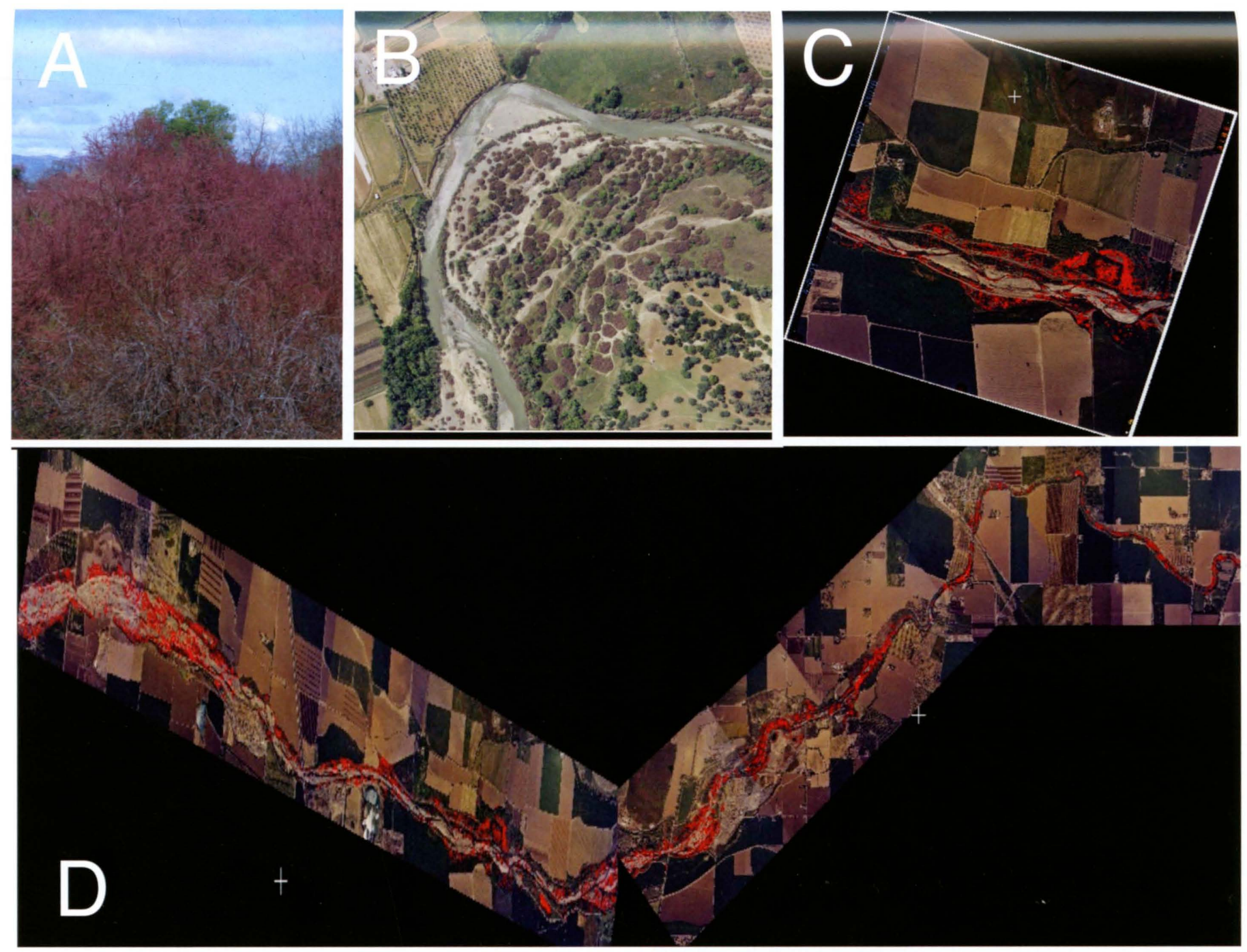

Plate 6. (A) In early spring, Tamarix parviflora blooms heavily with dark pink flowers prior to leafout. (B) Such blooming patterns aid in visual detection of this species from the air. (C) Aerial photographs of T. parviflora have been spatially georectified and digitally analysed using both colour and texturing techniques. (D) This allowed the development of a mosaic map showing the distribution and density of saltcedar along the watercourse, helping local land managers to plan AWPM of this invasive plant. 
7.

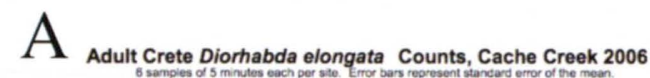
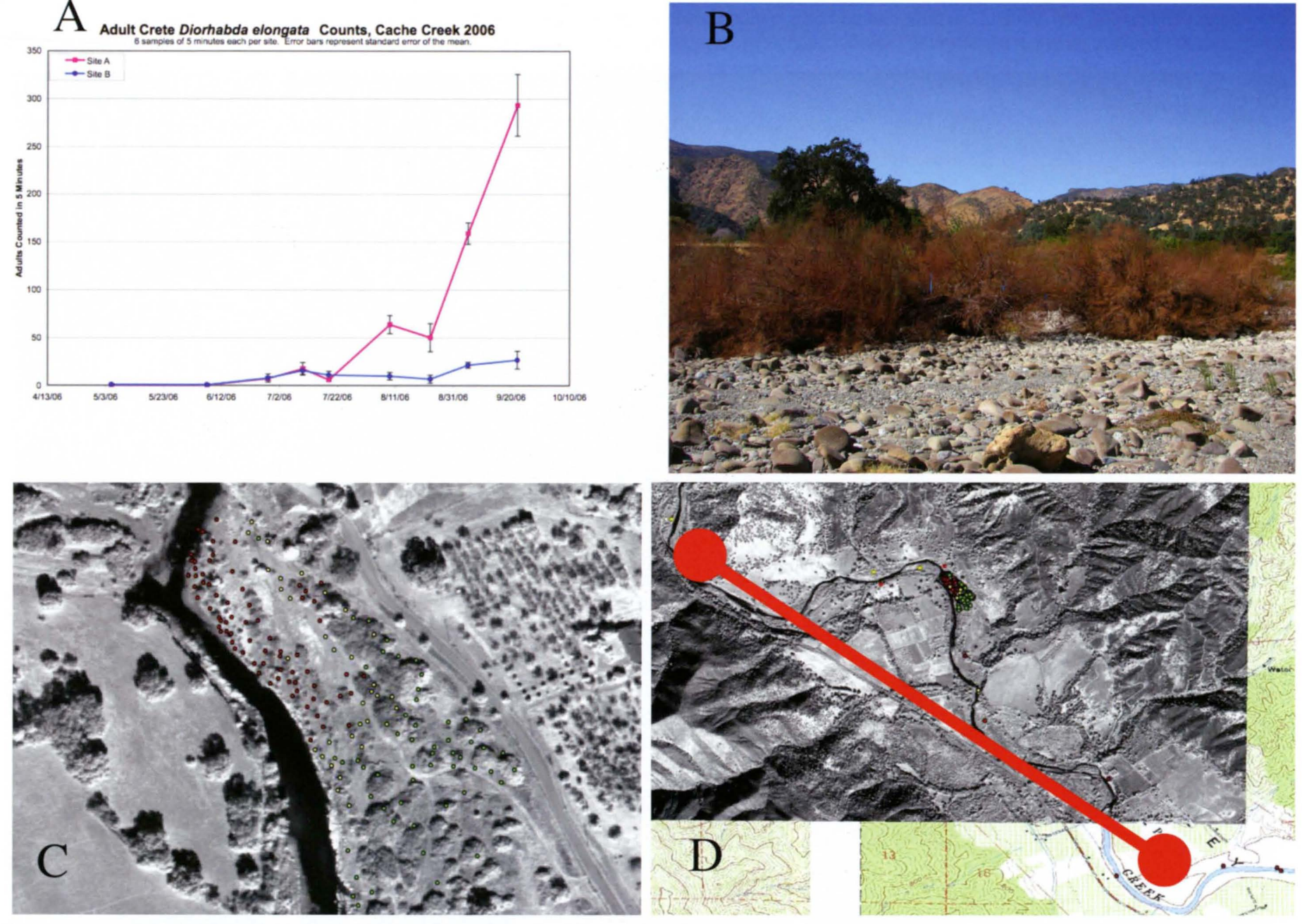

Plate 7. (A) Infestations start slowing right after the beetles are released, but grow exponentially as there are few natural enemies to limit their populations as seen in this graph depicting adult counts at the Cache Creek release area where beetles from Crete, Greece were released. (B) Once Diorhabda elongata numbers increase to a critical threshold level, heavy defoliation is seen on impacted plants near the release areas. (C) This heavy defoliation induces adult beetle movement that the AWPM project tracks first on the ground using GPS and vegetation sampling. (D) However, the beetles and the associated defoliation quickly spread, as in this Cache Creek release site where within a single season beetles were detected over an $8 \mathrm{~km}(5$ mile) stretch of habitat. 
8.

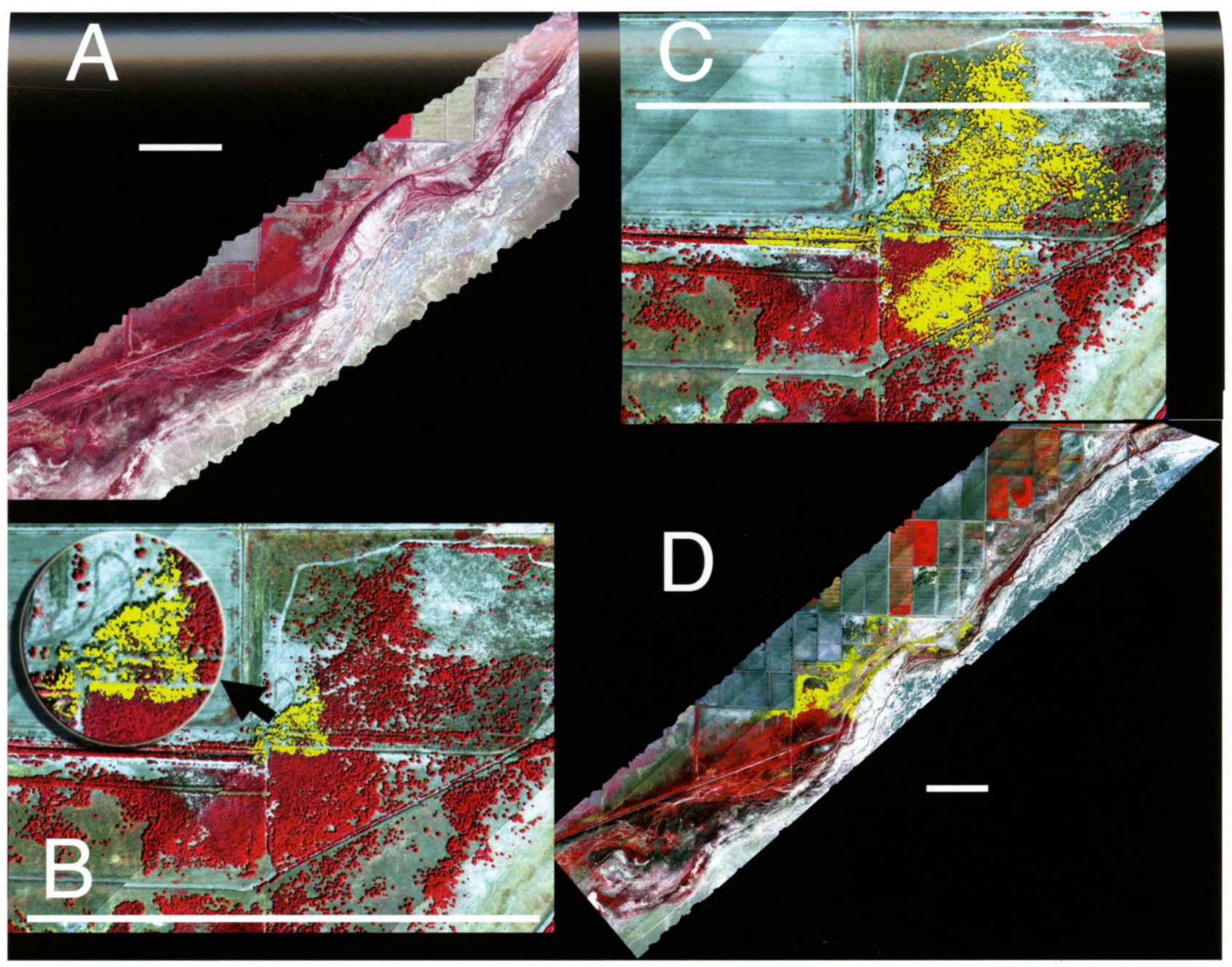

Plate 8. (A) An infrared image shows healthy saltcedar plants (red coloration depicts healthy vegetation) across the Lovelock, Nevada, release site in July 2002 (the white bar in each panel represents ca. $1 \mathrm{~km}$ ). (B) Note the yellow artificially coloured area $(0.35 \mathrm{ha})$, where the Diorhabda elongata beetles totally stripped the foliage by the end of August 2002. Note the loop road that can be seen next to the release site in Plate 4 ( $\mathrm{A}$ and $\mathrm{B}$ ). These hyperspectral images allow detailed assessments to be made over wide areas to track beetle impact through time. (C) In July 2003, the defoliated area had significantly expanded to over 3.4 ha of actual canopy and significantly more ground area.

(D) By September 2003, 76.7 ha of canopy had been totally defoliated, and repeated defoliation occurred within the entire test area impacted in previous beetle generations. 
9.

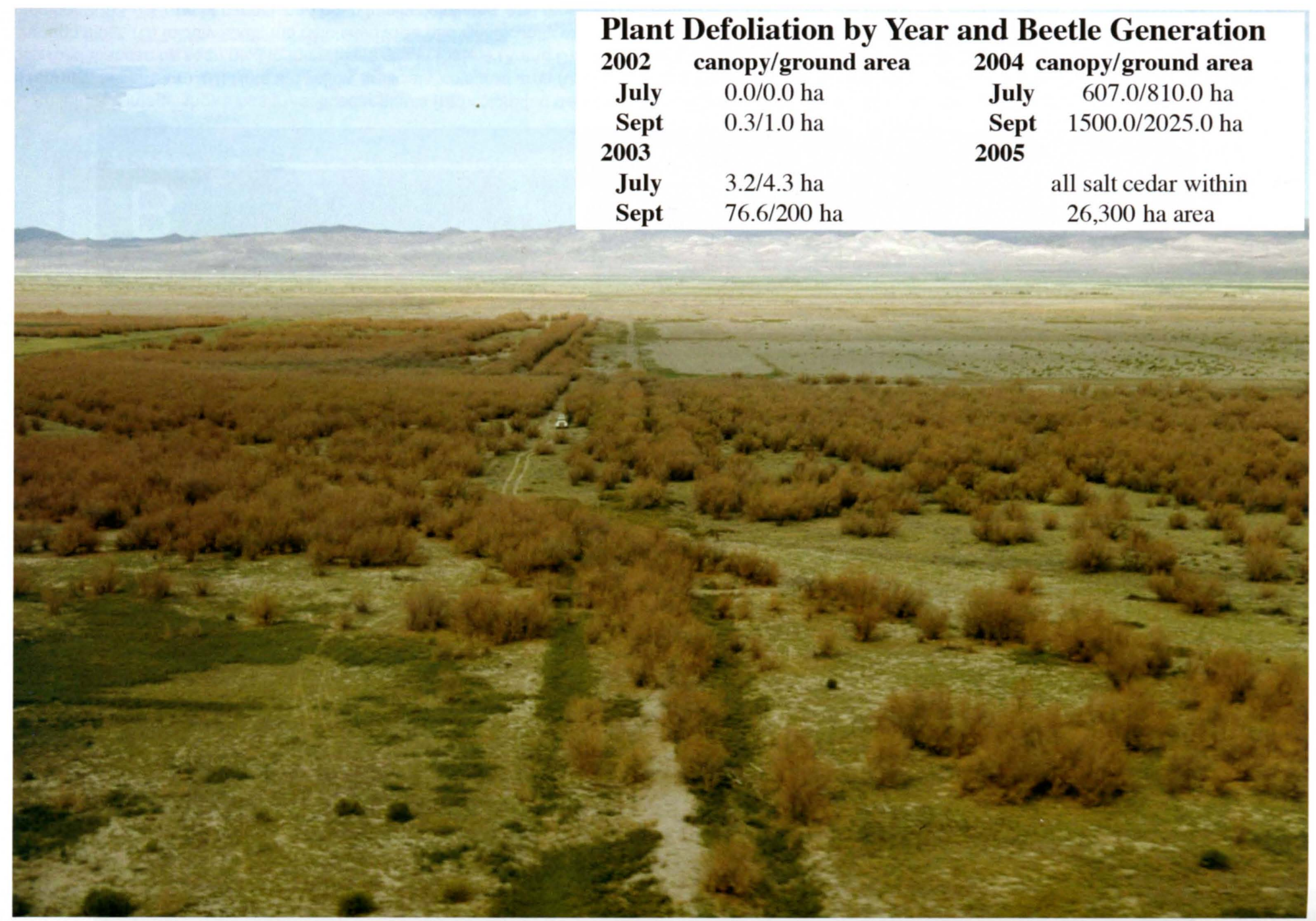

Plate 9. Beetle damage to saltcedar at Lovelock, Nevada, was tremendous by 2004, impacting thousands of hectares and was beginning to cause saltcedar mortality around the original release site. By 2005, beetles were found $>150 \mathrm{~km}$ from the original release area and most saltcedars in northern Nevada were impacted to some level with defoliation continuing to increase at all sites. 
10.
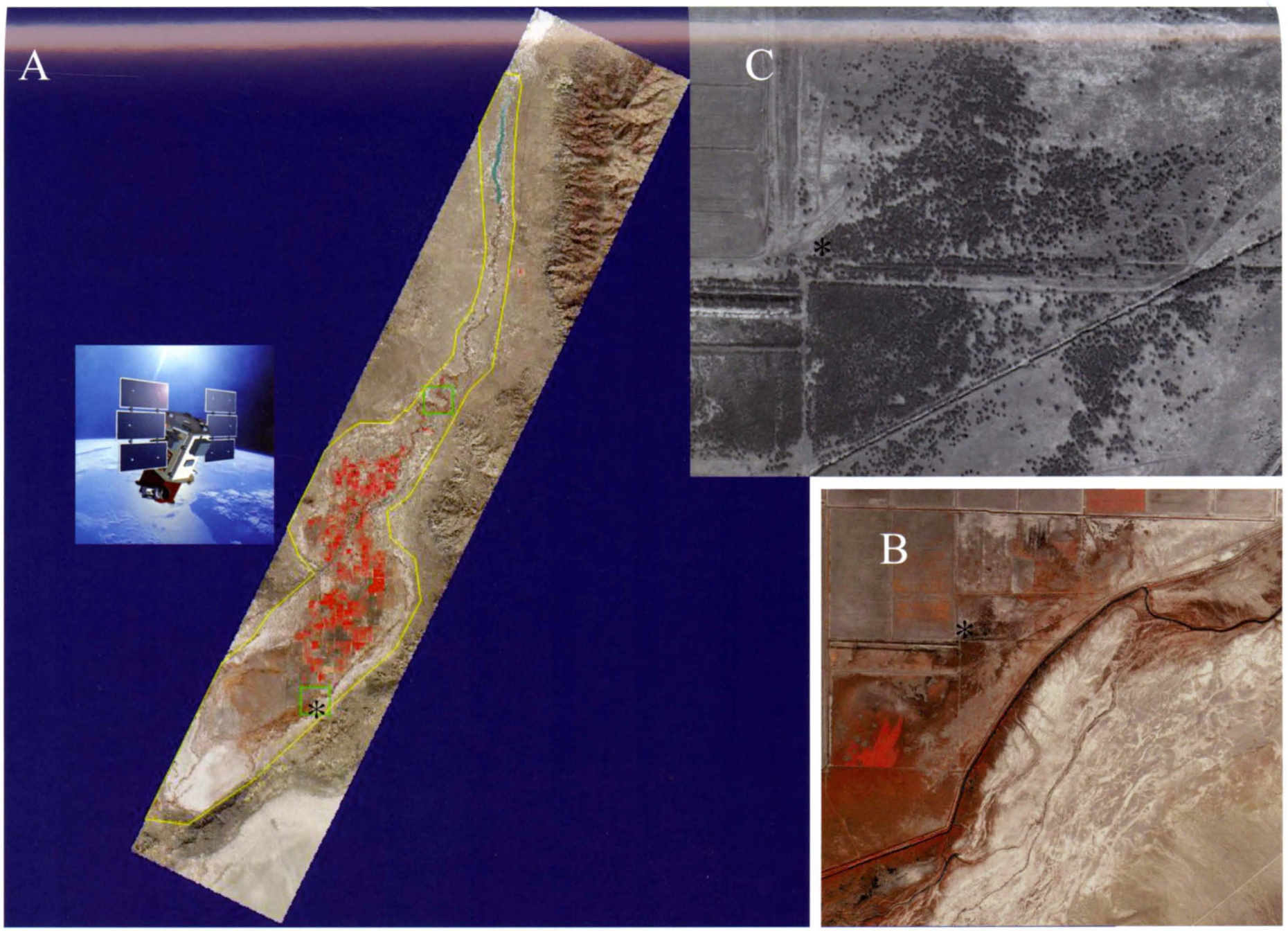

Plate 10. Neither ground nor aerial surveys proved adequate to assess the areas of defoliation caused by Diorhabda elongata across northern Nevada and Utah test sites. Alternatively, Quickbird satellite imagery was used to help assess saltcedar defoliation along the Humboldt River (An * indicates the original release site in all three images). (A) An approximate 80-mile swath representing multispectral Quickbird data collected to aid in defoliation assessment. (B) Shows a satellite depiction of the original Lovelock release site, again with the pinkish red coloration depicting green vegetation. (C) A maximum zoom image of the release site showing individual dying saltcedar with no signs of live vegetation. Imagery supplied by Digital Globe Corporation. 
but such prescribed fires typically thin salt cedar thickets enough to allow worker entry into an area where follow-up herbicidal applications can be made on plant regrowth. The USDI has used this approach in managing salt cedar in heavily infested areas of California (West, 2007; http://www.invasivespeciesinfo.gov/ docs/news/workshopSep96/west.html); however, it is typically very detrimental to native woody species such as cottonwoods and willows in the same or adjacent areas. One hundred-foot $(30 \mathrm{~m})$ buffer areas are recommended between treated zones and areas that are to be protected from the prescribed burn.

Bulldozers and other heavy equipment have also been used in attempts to control salt cedar, but since this plant easily resprouts from root fragments, it alone is typically not adequate to control this shrub unless repeated treatments or combined treatments with other control measures are used. Physical treatment of this type is also usually highly disruptive to local habitats and is the least economical and least desired method of control. In some circumstances, however, it has been one of the only ways to destroy heavily infested sites where fire is not an option, thus allowing land managers open access to areas that were previously unpenetrable for other ground-based control actions.

\section{Limitations of Current Management Approaches}

Although traditional approaches to salt cedar control may be successful in the short term they do not provide permanent control of the problem, as salt cedar often grows back or re-invades from surrounding areas. Such treatment also affects the quality of the treated habitat, which is typically degraded by the control action due to unwanted non-target impacts on native flora and fauna. Furthermore, most areas of infestation are spread along linear waterways or throughout a network of complex riverine tributaries within different-sized watersheds. Such watersheds may range from the extensive Colorado and Rio Grande River systems to localized areas such as isolated desert springs.

Due to the nature of most western riparian corridors, salt cedar infestations often cross many different political and ecological boundaries. Thus control programmes are not often implemented holistically, as the logistics of coordinating many landowners and managers across such geographic and political boundaries are often difficult, if not impossible. Thus localized implementation of any such control efforts usually has only short-term effects unless conducted cooperatively, by using watershed level practices to synchronize management actions and to avoid re-invasion.

When targeting small, isolated areas of infestation, labour-intensive cutting and stump treatment has been most effective. This approach has been successfully used by the National Park Service locally to eradicate salt cedar from restricted areas (see http://www.nature.nps.gov/biology/ipm/manual/exweedsl.cfm). On a larger scale, other management groups have targeted entire tributaries, such as major sections of the Pecos River in New Mexico and Texas, with broadcast chemical applications. On the Pecos River near Artesia, New Mexico, c. 2000 ha of salt cedar were treated from 2001 to 2004, with $85-90 \%$ kill.

Along the Pecos River, Texas from 1999 to 2004, 5169 ha of salt cedar along $434 \mathrm{~km}$ of the river and its tributaries have been treated, at a cost of US\$2.5 million 
(US\$407/ha), with 85-90\% kill (Hart et al., 2000, 2005; Hart, 2004, 2006), and the present cost is now US\$580/ha. Such areawide chemical application techniques often require several follow-up treatments to kill salt cedar regrowth and, when successful, are unfortunately equally devastating to most of the other vegetation in the area, as the chemicals used for salt cedar control have little or no selectivity. More environmentally sensitive cut-stump treatments require much more physical labour and often cost between US $\$ 2000$ and US $\$ 3000 /$ ha J. Watson, California, 2006, personal communication).

Such areawide chemical application programmes have achieved the organization of landowners and management groups within a watershed to obtain more complete control of salt cedar in order to limit re-invasion potential. However, planning and implementation is difficult and not always successful, as many landowners often do not want to invest the resources necessary to conduct such work, nor do they agree easily on the combined technology or the economics of the control effort. Effective follow-up is even more difficult, as once the primary control effort passes, sustained enthusiasm seems hard to maintain, especially as continuing investments are often required. Even when systematic watershed management practices are followed and the majority of the land is treated, re-invasion may occur across waterways through seed transport or other methods of movement. In these situations, parallel AWPM using biological control can significantly aid in lowering salt cedar densities by limiting regrowth and spread.

Furthermore, without adequate revegetation methods used in direct follow-up to such a scorched-earth policy, severe erosion problems can quickly destroy the rapid gains made by eliminating salt cedar, since other covering vegetation is also lost. Such rapid removal of all the vegetation from an area and the associated ecological disturbance may result in other noxious and invasive weeds repopulating treated areas rather than the desired beneficial vegetation. More gradual and sustained means of reducing and/or eliminating salt cedar significantly improve the long-term healing and sustainability of any such management practice, as they allow a more gradual transition from an infested to a restored state.

Use of AWPM with biological control as the central and unifying technology provides such an approach, as biological control typically requires 3-5 years of repeated defoliation to cause salt cedar mortality. Although biological control agent feeding may cause rapid leaf loss and limit water use very quickly, actual mortality is caused by the combined impact of the beetles, a declining photosynthetic capability of the weed and competition from other plants in the area, rather than by chemical toxicity of herbicides. Thus salt cedar mortality is often caused secondarily through competition with other plants in the local community that respond to increasing water and light availability, and thus are released by the decline in salt cedar vigour to repopulate areas where biological control has been used.

\section{Anticipated Benefits of AWPM}

We expect the areawide application of biological control of salt cedar to reduce, gradually (over a period of 3-5 years) and permanently (through longer periods of 
time) the abundance of salt cedar to below the level of economic or environmental damage, but not to eradicate it. In this situation, both salt cedar and the insects used for biological control would remain at fluctuating low population levels, and thus the agent or agents would always remain present at some level to rebound and control regrowth or re-invasion of windblown or waterborne seeds, if needed. Biological control can work alone or in combination with other methods of salt cedar control, depending upon the local needs of the land and waterways managers. In some areas, rapid knock-down of salt cedar is desired to facilitate flood control, fire management or other purposes, and then the biological control agents can be used to control regrowth or, if control over a longer period of time is desired, insects can be used alone or with follow-up treatments using other control methods.

Under most conditions, we expect the native plant communities to re-establish naturally in areas where depth to water table and soil salinity are not too great. This should improve wildlife habitat and allow the recovery of many species of birds and fish and some mammals and reptiles, including several threatened and endangered species. Control of salt cedar is expected to increase the amount and quality of water available for irrigated agriculture and municipal and environmental use, and to help fulfil the interstate water rights agreements and between the USA and Mexico.

Control is also expected to increase recreational usage of parks and wildland areas, to reduce wildfires and to allow the gradual reduction of salinity levels of surface soils in presently infested areas. Large-scale revegetation projects are also under development by the USDI Bureau of Reclamation for areas where natural revegetation may be insufficient (Lair and Wynn, 2002). In some areas where salt cedar has formed extensive monocultures for many decades, where the natural hydrologic cycles have been interrupted, soil salinity increased or water tables lowered, natural revegetation is unlikely and will require additional interventions.

Since biological control is a gradual process rather than a quick-acting control method such as chemical and physical control, and also since it is target selective, we feel that it holds the best potential for allowing various habitat restoration processes to be developed and implemented gradually, where other controls would not be easily compatible with recovery efforts.

\section{Description of the AWPM Programme and Approaches}

The low beneficial value of salt cedar, its lack of closely related plants in the Western hemisphere and the large number of host-specific and damaging natural enemies that attack it within its native distribution in the Old World, make salt cedar an almost ideal invasive weed for an AWPM programme using biological control as its keystone technology. Over the past decade, biological control of salt cedar has seen a major research effort within the USDA-ARS and its cooperators. A consortium of scientists and land managers has recently developed and field-tested the use of this new technology in several western states, including California (CA), Colorado (CO), Montana (MT), New Mexico (NM), Nevada (NV), Oregon (OR), Texas (TX), Utah (UT) and Wyoming (WY) (see DeLoach et al., 2004). 
The programme began with surveys for potential natural enemies carried out in Italy, Israel, Iran, India, Pakistan (Gerling and Kugler, 1973; Habib and Hassan, 1982) and Turkey (Pemberton and Hoover, 1980), together with extensive ecosystem studies in the former Soviet Union (Mityaev, 1958; Kovalev, 1995) and by our team in China and Kazakhstan (Li and Ming, 2001-2002; Mityaev and Jashenko, 2007).

This combined team effort revealed over 300 specific and highly damaging insect species that are now being considered as potential biological control agents for salt cedar. Research began at Temple, TX, in 1986, with a thorough review of the literature and an analysis assessing the benefits and risks of such a programme (DeLoach et al., 2004). Overseas testing of control agents was then begun under quarantine condition at Temple, TX, in 1992 (see DeLoach et al., 1996) and in Albany, CA, in 1998 (see Lewis et al., 2003a).

\section{AWPM management technologies and approaches}

The leaf beetle, Diorhabda elongata deserticola Chen (1961), was selected as the first potential introduced biological control agent of salt cedar, since it was observed to severely defoliate this target plant in research sites in China, Kazakhstan and other Eurasian locations. Defoliation was typically heavy as the beetles attacked in mass, causing vegetative damage that induced severe dieback of most branches on affected plants. In these native areas, most defoliated salt cedar resprout from the base of the plant late in the season, with the next generation of insects either continuing to feed on these same plants or moving on to other adjacent plants, allowing the impacted stand to recover.

Diorhabda elongata populations in these areas were limited by their own suite of natural enemies, most notably a tachinid larval parasite (Erynniopsis antennata (Rondani)) and a microsporidian pathogen (Nosema spp.), and thus rarely reached extremely high population densities in native areas (a factor that does not hold in North America once top-down population regulators were removed from the system in quarantine).

In Eurasia, an ecological balance seems to have been established between low densities of the native salt cedars, the many diverse natural enemies that use the plant and their associated parasites and predators in areas of origin. The leaf beetle, however, seemed very appropriate as a potential biological control agent of salt cedar, as it caused high levels of defoliation (for short times in limited areas), had a high reproductive rate and further exhibited extensive dispersal capabilities in nature. Thus, in March 1994, a petition was submitted to USDA Animal and Plant Health Inspection Service (APHIS) Technical Advisory Group on Biological Control of Weeds (TAG) in 1998, allowing for the caged release of the leaf beetle D. elongata from China and Kazakhstan into several western US states. This was the beginning of the research and developmental phases of the AWPM programme for salt cedar control in the USA.

Thus, D. elongata was selected as the first of ten priority agents for consideration as a manipulated biological control agent to be used in North America, and will be the only insect discussed here (see DeLoach et al., 1996 for a discussion of other 
potential biological control agents). Parallel studies on $D$. elongata biology, host specificity and efficacy were outlined and implemented by our internal USDA-ARS AWPM team and affiliated members of the Saltcedar Biological Control Consortium, formed in 1998 (see section on Technology Transfer and Education). Through joint efforts of this consortium and core project scientists, funding for a coordinated research and developmental programme was acquired through competitive selection of a USDA-CSREES-IFAFS grant. Without such funding, an AWPM approach and the regional testing and development would not have been possible (Carruthers et al., 2000; Carruthers, 2003, 2004).

The biology of $D$. elongata - from both Fukang, Xinjiang Autonomous Region, China and from Chilik (120 km ENE of Almaty), Kazakhstan (see Plate 2a-e) - was assessed by our team in Kazakhstan (Mityaev and Jashenko, 1999-2005), in China (Li and Ming, 2001-2002) and at Temple, TX, Albany, CA and the other various release sites in the USA (see subsequent sections). Both adults and larvae of $D$. elongata feed on the foliage of salt cedar, and the large larvae also de-bark small twigs causing the distal foliage to die. The adults overwinter and the larvae pupate under litter and in the soil beneath the trees. In the laboratory, an average female oviposits approximately 200 eggs over a 12-day period, but can live up to several months (1-3 months) in the field.

Lewis et al. (2003b) measured the duration of each life stage, calculated an optimal net reproductive rate $\left(\mathbf{R}_{0}\right)$ of 88.2 , time per generation $(T)$ of 39.9 days and the rate of increase, showing that the population can double each 6.2 days. Further temperature-dependent developmental and survival characteristics were measured and used to construct predictive models to estimate phenology, survival and reproduction under both insectary and field conditions (Herrera et al., 2005). Field cage studies conducted in multiple sites revealed a range of population increases by location, averaging approximately 30 -fold per generation (DeLoach et al., 2004).

The synchronization of the beetle life stages with normal salt cedar leaf-out enables the overwintering beetle adults to emerge from April to early May, depending upon heat accumulation patterns in the local area and, after a short preovipositional period, to lay eggs from early April to late May. First-generation larvae are typically present from May through June, pupate in the leaf litter/soil interface under the salt cedar and then emerge as first-generation adults in late June-mid-July. In most areas north of the $38^{\circ}$ parallel, where the daylength is sufficient, the first-generation adults reproduce actively and initiate a second generation of larvae that follow the same general cycle as the first generation.

In all areas the beetles end the season as adults, emerging over a period from August to October, depending upon local conditions. The second-generation adults feed for a short time, rarely oviposit and then aggregate in the soil/litter interface where they overwinter in high-density masses, often of thousands of beetles or more. In warmer locations with earlier spring warm-up, such as California and southern Texas, beetles can emerge as early as late March and may have up to four or five generations within a growing season, as they also stay active much later into the autumn.

Heavy population densities, especially of large larvae and adults, can produce severe defoliation in one or more generations, each year. In the more southern areas, where the salt cedar growing season is longer, some strains of beetles may 
complete four or more generations in a single season. The number of generations of beetles is dependent upon their temperature-dependent developmental rates (Herrera et al., 2005) and their diapause induction characteristics, which are affected by a combination of temperature and photoperiod (Lewis et al. 2003b; Bean et al., 2007a, b).

The initial populations of beetles from western China and Kazakhstan were not well adapted to the more southern latitudes of the south-western USA such as California, New Mexico and Texas. For that reason, additional biotypes (potentially different species, although not yet documented in the taxonomic literature) were collected from more southern latitudes in Eurasia and North Africa, and were then used successfully in the south-western areas of the USA (see Carruthers et al., 2006, 2007; DeLoach et al., 2007a, b). Signs now indicate that potential selection among the original stocks from China and Kazakhstan may be occurring, and thus may become adapted in terms of diapause induction to more southern latitudes (Thompson et al., 2007).

Extensive host range testing overseas, in conjunction with quarantine tests conducted at Temple, TX and Albany, CA, indicated that D. elongata is very host-specific in its feeding patterns and is virtually restricted to feeding on invasive salt cedars in North America, with the exception of potentially feeding on a group of herbaceous to shrubby plants in the family Frankeniaceae, Order Tamaricales.

The D. elongata Fukang/Chilik ecotype was extensively tested for its ability to develop, reproduce and complete its entire life cycle on 84 different test plant accessions, including six species and 26 accessions of Tamarix, four species of the somewhat related and native Frankenia and 71 species of more distantly related plants, habitat associates, agricultural crops and ornamental plants in 24 families in more than 24 tests over 14 years (DeLoach et al., 2003; Lewis et al., 2003a; Dudley and Kazmer, 2005; Milbrath and DeLoach, 2006a, b; Herr et al., 2007).

The most at-risk species were found to be Frankenia salina (Molina) I.M. Johnston, F. jamesii Torrey and the formerly endangered F. johnstonii Correll. Extensive additional testing of Frankenia was conducted under APHIS permits in the laboratory, greenhouse, field cages and, eventually, in the open field. These tests demonstrated that D. elongata from both Fukang, China and from Chilik, Kazakhstan, were safe to release in the field. Similar laboratory testing was conducted on six other strains of beetles collected at later dates, but only strains from China, Kazakhstan and Greece received the full battery of tests that warranted field release into areas where $F$. salina, the most at-risk species, was present (Herr et al., 2007).

Open-field tests conducted on the most vulnerable species indicate that, on Frankenia spp., we expect only occasional attraction to, or feeding and oviposition on, the plants, if they grow adjacent to Tamarix. Although possible, we do not expect the beetles to develop self-sustaining populations on Frankenia, nor do we expect Frankenia to be a sustaining host plant in nature (see Milbrath and DeLoach, 2006a, b; Herr et al., 2007). In parallel with all beetle releases, forced selection studies have been and are continuing to assess potential host shifts in the laboratory, and additional field testing and monitoring of $F$. salina is also being conducted, and will continue for several years to assess any possible unwanted negative impacts with time; however, none are anticipated. 


\section{Compatibility of the AWPM programme with crop management and management of co-occurring pests and native species}

Currently, salt cedar is controlled in most locations as a single, invasive species; however, it can co-occur with a number of other invasive weeds in complexes that differ with geographical location. These species vary across the western USA, but include problematic weeds such as giant reed (Arundo donax L.), tall whitetop (Lepidium latifolium L.), yellow starthistle (Centaurea solstitialis L.), Russian knapweed (Acroptilon repens (L.) D.C.) and Russian olive (Elaeagnus angustifolia L.). Individual land management teams currently deal with these species as follow-up problems after first controlling for salt cedar to increase access to infested riparian corridors. This control is typically conducted chemically or through physical removal of associated weed species. No integrated multiple species pest control efforts have been developed or implemented to control these assemblages of invasive weeds; however, USDA-ARS has initiated new biological control efforts for most of these species and, hopefully, new natural enemies will be incorporated into more holistic integrated weed management programmes, once they become available.

However, additional effort has been directed toward making AWPM of salt cedar compatible with the management of other beneficial species, including native willows and cottonwoods, which represent natural vegetation that is desired in many riparian areas, along with an assemblage of other native and beneficial plant and animal species. In fact, much effort is currently oriented toward revegetation technologies (Lair and Wynn, 2002), and is discussed in a previous section. One ongoing issue of compatibility, however, still exists with the use of AWPM for biological control and the management of an endangered native bird.

The listing of the south-western willow flycatcher (Empidonax trailii subsp. extimus Phillips (SWWFC)) as federally endangered, in March 1995, required consultation with FWS and the preparation of a Biological Assessment, which was submitted to FWS Region 2 (Albuquerque, NM) in October 1997. This analysis revealed that the flycatcher used salt cedar extensively for nesting habitat in some areas of Arizona, but little in adjacent states, and that other potentially harmful effects of salt cedar reduced reproductive success of the flycatcher to half of that in its native willow habitat (DeLoach and Tracy, 1997; DeLoach et al., 2000).

Due to potential impacts of rapidly reducing salt cedar canopies through extensive defoliation and the questionable impact to nesting sites of an endangered subspecies of bird (the SWWFC), the project was allowed to proceed only slowly, in phases and in locations over 200 miles from SWWFC nesting sites. The US FWS required that initial beetle releases be conducted within cages and then gradually scaled up to open-field releases once experience had been gained on the beetle's biology and impact under North American conditions. Thus, the AWPM effort followed both timelines and monitoring requirements set through negotiations between the regulatory agencies (US FWS, USDA-APHIS and various states), USDA-ARS and the Saltcedar Biological Control Consortium.

To further assess this situation, a research proposal to FWS was submitted on 28 August 1998 (DeLoach and Gould, 1998). It specified a research phase in which:

- Diorhabda elongata could be released into secure field cages at ten specified sites in different climatic zones in $\mathrm{CA}, \mathrm{CO}, \mathrm{NV}, \mathrm{TX}$, UT and $\mathrm{WY}$, all more than 
200 miles from where the SWWFG nests in salt cedar. The beetles were to be carefully monitored in the cages for 1 year to determine their overwintering ability, mortality factors, rate of increase and damage to salt cedar and non-target plants in the cages.

- The beetles then could be released into the open field over a 2-year period, during which the degree and rapidity of control, rate of natural dispersal and effects on native plant and wildlife communities would be monitored.

After this combined 3-year test period, FWS, ARS and APHIS would review the research results and determine the conditions under which an Areawide Implementation Phase could be conducted. A Letter of Concurrence was issued by FWS on 28 December 1998 (revised 3 June 1999) and an Environmental Assessment was prepared by USDA-APHIS on 18 March 1999. APHIS issued a Finding of No Significant Impact (FONSI) on 7 July, and permits to release in field cages during July 1999.

By taking this approach, it significantly slowed the development of AWPM of salt cedar, but it has also provided much experience with salt cedar control in areas away from the SWWFC, and thus scientists working in the areas where this bird nests in salt cedar are better prepared to consider using biological control as a management option in the future. Currently, no such programme is planned for the heart of the endangered SWWFG habitat in AZ, but programme expansion into parts of NM and southern $\mathrm{CA}$ will soon require that this issue be addressed.

\section{Development and Implementation of the AWPM Programme}

\section{Experimental releases and results in field cages: July 1999-May 2001}

Diorhabda elongata desericola from Fukang, China, were released into field cages during July and August 1999 at eight sites (see Plate 3) on a privately owned ranch near Seymour, TX; on Bureau of Reclamation land near Pueblo, CO; National Park Service lands near Lovell, WY; Paiute Indian tribal lands near Schurz, NV; a privately owned farm near Lovelock, NV; Los Angeles County Water District lands near Bishop, CA; and Hunter-Liggett Military Base, near Lockwood, CA. Beetles from Chilik, Kazakhstan were released on Bureau of Land Management land near Delta, UT.

During the spring of 2000, beetles from Fukang also were released into cages at Stillwater National Wildlife Refuge near Fallon, NV and on private land at Cache Creek near Woodland, CA. These beetles successfully overwintered in the cages at the eight most northerly sites, although only weakly so at Stillwater and Cache Creek. They failed to overwinter at the two most southerly sites, at Seymour, TX and Hunter-Liggett, CA. At the six sites where strong overwintering occurred (Pueblo, CO, Lovell, WY, Delta, UT, Lovelock and Schurz, NV and Bishop, CA), the beetles increased to large numbers during the summer and completely defoliated the plants inside the cages during both 1999 and 2000. The two generations of larvae during June and August produced extensive damage to the caged salt cedar, such that additional cages had to be established over fresh plants where beetles were transferred to preserve the outdoor colonies. After the failure to overwinter at the most southern 
sites, the beetles were restocked but failed to reproduce, entered diapause in early July, and again failed to overwinter.

Field observations and experiments in outdoor cages indicated that the most probable cause of the failure to overwinter and reproduce was the short summer daylengths at latitudes below $38^{\circ}$ (see Lewis et al., 2003b; Bean et al., 2007a, b), which induced premature diapause. Daylength near the origin of these beetles at Fukang $\left(44^{\circ} 17^{\prime} \mathrm{N}\right)$ and Chilik $\left(43^{\circ} 33^{\prime} \mathrm{N}\right.$ latitude) attains a maximum of $15.5 \mathrm{~h}$; maximum daylength at more southerly locations in the USA was only around $14 \mathrm{~h}$.

In follow-up laboratory studies, Bean et al. $(2007 \mathrm{a}, \mathrm{b})$ determined that $D$. elongata from Fukang required at least $14.75 \mathrm{~h}$ daylength to avoid entering overwintering diapause. Thus, in the most southerly release areas, the beetles often began diapausing in early July without adequate winter reserves to survive the extended time in dormancy (Lewis et al., 2003b).

These findings led to further overseas exploration and the acquisition of additional beetle strains from a wider latitudinal gradient, from North Africa, through Europe and into Western Asia, to supplement existing populations of D. elongata from Kazakhstan and China. Thus, the programme proceeded as planned in the more northerly areas toward open-field releases of beetles, and worked to assess potential new germplasm for use in more southerly locations.

Currently, beetles from Crete (Greece) are the primary insect natural enemy being successfully used below the $38^{\circ}$ parallel; however, investigations are continuing on other potential beetle populations, which will be used as needed where the currently released beetles seem ecologically unsuitable. See DeLoach et al. (2007a, b) for an up-to-date assessment of the different ecotypes of beetles currently being used in this programme throughout the country.

\section{Releases and results in the open field in northern areas: May 2001-late summer 2006}

The results of the releases into field cages and of the additional test results of D. elongata deserticola were submitted to USDA-APHIS and the US FWS on 25 August 2000 , requesting releases into the open field. These permits were granted and adult beetles were released into the open field beginning May 2001 at the six sites where the beetles had successfully overwintered in cages. Additional releases were made during the remainder of the year as beetles were produced in nursery cages. Altogether, approximately 27,000 adults and larvae were released at Lovell, WY; 6900 adults plus many larvae at Pueblo, CO; 15,000 at Delta, UT; 3500 at Schurz and 1400 at Lovelock, NV; 4400 larvae and 2000 adults at Bishop, CA; and 498 adults at Seymour, TX. Upon release, the beetles typically dispersed rapidly and were difficult to observe in large numbers in or around the release area.

At most sites, only a few to moderate numbers of eggs, larvae and adults were found in the field throughout the remainder of the summer of 2001, until late August or early September, when no more insects were found; and thus we assumed that the adults had entered overwintering diapause. In the autumn of 2001, the most severe damage was observed at Pueblo, CO, where the beetles defoliated approximately 
two-thirds of a rather large tree about $10 \mathrm{~m}$ from where they had been released. Similar low densities of beetles were found during the spring and early summer of 2002 , and were detectable only over an area of $c .50-100 \mathrm{~m}$ in radius from their release points.

Then, when large larvae of the second generation developed in mid-August, extensive damage was found at some sites. The most spectacular impact was in Lovelock, NV: tremendous populations of large and some medium-sized larvae were found on 13 August that rapidly defoliated salt cedar trees near the original release site. On 28 August, the larvae had destroyed 95-98\% of the foliage of all trees within an area $100 \mathrm{~m}$ in diameter $(<1 \mathrm{ha}$ ), centred at the release cage (see Plate 4 ). Heavy feeding, but not total defoliation, had occurred in an additional concentric ring $50 \mathrm{~m}$ wide outside the core of the affected area (DeLoach et al., 2004).

By the end of the third growing season in late August 2003, the Fukang/Chilik ecotype of $D$. elongata had begun a rapid and dramatic defoliation of salt cedar at five of the seven release sites north of the 38th parallel. At Lovelock, NV, the beetles had defoliated $c .1$ ha of a dense stand of salt cedar in early September 2002 (total area of land infested by salt cedar, not canopy cover of the trees), which had increased to 4.3 ha by early July 2003, and to $c .200$ ha by early September 2003, along a $5 \mathrm{~km}$ reach of the Humboldt River (Carruthers et al., 2005). By September 2003, several plants had resprouted profusely from the base and occasionally from the upper branches, but enough beetles had remained in the stand to totally defoliate this regrowth. At Schurz (see Plate 5), the beetles had defoliated c. 12 ha along the Walker River.

By the end of the third growing season after release (late June 2004), defoliation by the Fukang/Chilik beetles at five northern sites had increased by three- to fivefold over the amount in August 2003, to an estimated 600 ha at Lovelock and 120 ha at Schurz. Defoliation increased exponentially in most release areas, both in terms of the insect numbers, their linear spread and the area of salt cedar impacted. By the summer of 2006 many thousands of acres had been totally defoliated at most of the release sites. Most significantly, as of late 2006, trees at the centre of the release sites were beginning to die. For example, approximately $65 \%$ of the trees defoliated in 2002 at the site in Lovelock (see Plate 4) were completely dead (T.L. Dudley, California, 2006, personal communication), and we expect to see increasing whole-tree death in wider areas in 2007.

Although salt cedar mortality took several years, the repeatedly high levels of defoliation (95-100\% for each generation) have reduced normal plant respiration and transpiration significantly each season, thus reducing salt cedar water usage to very low levels, and virtually eliminating seed production in most defoliated areas. This defoliation has also opened the canopy, allowing other plants to begin increasing in growth and number. Bird populations have increased at some sites, including Lovelock, NV, due to the increased food supply consisting largely of high populations of $D$. elongata beetles (Longland et al., 2007). Additional releases of the Fukang/Chilik beetles have now been made in several different states, both as research test sites and in an AWPM implementation effort conducted by USDA-APHIS, various state Departments of Agriculture, weed control districts and private landowners. Nursery sites have been set up in several western states (ten sites approved in each of the participating states) where establishment has been achieved at many locations; however, quantitative results from this effort are not yet available. 
Based on further laboratory and field assessments, D. elongata beetles from Greece were chosen as being the most likely strain of beetles to work effectively in more southern climates, and thus have been fully safety tested and released into both TX and CA, where they have successful overwintered and are now causing similar levels of defoliation to those seen in the early release years in the more northerly areas (see Carruthers et al., 2006, 2007; DeLoach, 2007a, b). The areas impacted by these beetles are still small $(<50 \mathrm{ha})$; however, population expansion is following a similar trajectory to the increases seen with the northern beetles released in 2001 (more details provided in a subsequent section). Further expansion of the associated acreage and the resulting impact on salt cedar is expected in these southern locations during the spring and summer of 2007.

\section{Development and implementation of education and technology transfer programmes}

Cooperator and customer education and technology transfer were considered and planned for very early in the development of the AWPM programme for salt cedar. In fact, outreach efforts began prior to any North American field experimentation on the project. This was done in a variety of ways, but most importantly through the formalization of the Saltcedar Biological Control Consortium (SBCC). The SBCC was organized in November 1998 to provide coordination between agencies and to obtain input, guidance and oversight in the research programme from users and environmental organizations, and to solicit political and monetary support in furthering the project (Stenquist, 2000).

The group has met annually since then, and now has representatives from $c .50$ federal and state agencies, universities and private user and environmental groups. The consortium was instrumental in gaining user support, developing and implementing operational plans and served as a means of linking critical groups into functional units that moved the wider-scale project forward through complicated partnerships with wide-ranging programme goals. It also allowed diverse input from all interested parties, providing dialogue and a means for rapid negotiations of any critical or controversial issues.

Only through the activities of the consortium were roadblocks removed regarding release of biological control agents because they had the potential to affect the endangered SWWFC. Such openness of operation and willingness of all parties holistically to address the salt cedar problem allowed a successful path to open. This and other similar situations typically required concessions from all sides but, through time, such discussions built trust and accelerated programme success. For example, the consortium explicitly developed a detailed monitoring plan that allowed the US FWS to issues its concurrence with both field-cage and open-field releases of the first salt cedar biological control agents. Without this linkage, the programme might never have met these first critical milestones. Additionally, several other outreach activities, such as symposia, extension brochures, joint agency press releases and educational information, were developed and released using the consortium as a clearing house. 
Maintaining a team independent of any one group or governmental agency proved beneficial, as it depolarized many potential problems and cross-agency conflicts. Subsequently sister groups, such as the Tamarix Coalition in Grand Junction, $\mathrm{CO}$ and the Rio Grande Institute in western TX, were organized as local extensions or partners with the original consortium, and have worked effectively to accelerate local projects using the salt cedar AWPM technologies. Most recently, a new TX, NM and Mexico section of the SBCG was formed to provide guidance and coordination for the special circumstances encountered in this southern area. Standing committees of these consortia include subcommittees such as: Science and Research, Wildlife and Environment, Federal, State, Private Liaison, US-Mexico Relations, Native American Relations and Public Education/Information (DeLoach et al., 2005). The SW Consortium group, in particular, was instrumental in obtaining approval from the Mexican Government in early 2007 to expand the AWPM of salt cedar into the Rio Grande River and northern Mexico. For more complete information on organization and activities see the web site at http://bc4weeds.tamu.edu/ weeds/rangeland/saltcedar-bcc-2005.pdf

\section{Evaluation of the AWPM Programme}

\section{Effectiveness of the AWPM programme at controlling the target pest}

The leaf beetle, $D$. elongata, has now been tested at several locations, where it has established reproductive populations, increased dramatically in numbers and spread extensively across salt cedar-infested areas where the beetles have caused extensive defoliation of salt cedar for multiple seasons (see Plates 4 and 5). In these test locations, the leaf beetles are significantly impacting salt cedar growth and development, while no non-target plants have been negatively affected (see examples in Plate 5 and in DeLoach et al., 2005). Such qualitative statements are true, but not often convincing to the scientific community or the regulatory agencies responsible for permitting the use of biological control technologies.

Thus, to quantitatively assess the effectiveness of this programme and to ensure environmental safeguards, a comprehensive monitoring programme was developed through the SBCC, approved by the USDA-APHIS and US FWS permitting units, and implemented by our project personnel. Ground sampling of beetle populations and their impact on target salt cedar and adjacent beneficial species was conducted at all of the release sites, along with various assessments targeting revegetation of beneficial plants and assessment of impacts on local and migratory wildlife. This was accomplished through an intensive monitoring programme that was designed by the SBCC and was carried out as required by the FWS Letter of Concurrence and the APHIS permits, as described in the Research Proposal to FWS of 28 August 1998 (Gould $e t$ al., 2000). This included both monitoring of the insects and plants in the initial field cages, and then open-field assessments conducted both pre- and post-release.

The basic open-field monitoring plan specified a 10 ha sampling circle centred at the beetle release point, with 100 permanently marked sentinel salt cedar trees with 25 trees in the inner 1 ha circle, 25 trees in a middle 2 ha concentric ring and 
50 trees in an outer 7 ha ring, these trees being divided equally and at random within each quadrant of each ring.

Diorhabda elongata and other insect populations, percentage defoliation produced, plant growth and condition were measured periodically on four marked, $40 \mathrm{~cm}$-long branch terminals on each salt cedar tree. Once annually the vegetation was sampled by measuring tree height and diameter, estimating percentage healthy vegetation, yellowing or dead branches and estimating the distance, species identification and size of the three nearest neighbour trees. Understorey vegetation was also measured in two $1 \mathrm{~m}^{2}$ quadrats, one under and one outside the tree canopy, in which percentage cover of all species and of litter and bare soil was estimated. This sampling plan was appropriate initially, and shortly after release, but became inadequate because the beetles rapidly overflowed this area and completely defoliated the entire sampling circle at most release sites. A modification such as the inclusion of longer transects (up to several $\mathrm{km}$ ) was initiated using sentinel trees where similar data were collected.

Additionally, timed adult beetle counts were used to follow low-level beetle populations and, later, a beetle pheromone and a salt cedar extract were formulated (Cossé et al., 2005) that were very attractive to D. elongata beetles from China and Kazakhstan over distances of 10-20 m. These baits were incorporated into a trapping system and have been effectively used in monitoring the dispersal of the beetles at Lovelock, NV and other locations.

All of these techniques aided local site managers in assessing overwintering success, beetle movement and eventual spread into new areas. The results from this monitoring were extensive and varied from test site to test site, but have been summarized by DeLoach et al. (2004, 2005, 2007a, b) and various other unpublished consortium reports. Here, we will summarize the impact and results of this programme primarily through the use of remote sensing and GIS visuals later in this section, as these techniques give a more comprehensive impression of the beetle spread, defoliation and impact.

In addition to the vegetation- and beetle-monitoring methods, a number of wildlife species were also assessed. For example, a bird-monitoring plan combined two riparian sampling areas that were selected, one with near-monotypic salt cedar and one with nearly pure native vegetation. In every area ten permanent point-count areas were located, each $100 \mathrm{~m}$ in diameter and separated from each other by $100 \mathrm{~m}$. Three times annually during the breeding season, the numbers of each bird species seen or heard are counted from the centre point of each circle. This allowed a direct comparison between salt cedar and native vegetation, and also of populations in salt cedar before and after biological control, with the native vegetation plots used as a statistical control.

Results from such monitoring assessments showed that, initially, salt cedar had fewer numbers and less diversity of native birds inhabitating areas of invasion than adjacent areas populated with native plant species. As defoliation increased, birds moved back into the areas where AWPM using $D$. elongata was under way, where they used the insects as a food resource. With time, we expect other native plant populations to increase in beetle areas, and the relative amount of salt cedar should further provide more diversity of habitat, feeding and nesting space for many bird species (see DeLoach et al., 2005; Longland et al., 2007 for more details). Procedures also have been developed for monitoring butterflies, other insects, small mammals and reptiles, but will not be discussed here (see DeLoach et al., 2005). 


\section{Monitoring through remote sensing}

In the first 2 years following beetle release, ground-based sampling proved adequate; however, the scale of beetle population growth, spread and impact quickly made ground-based field sampling difficult, expensive and thus impractical. Previous studies (Everitt and DeLoach, 1990) have documented the effective use of remote sensing for the assessment of salt cedar infestations. In support of the overall project monitoring and assessment efforts, remote sensing was conducted to characterize salt cedar infestations, to follow beetle establishment, impact and spread and, eventually, to document the return of beneficial vegetation into areas where salt cedar has been controlled.

A comprehensive assessment programme has used a combination of colour aerial photography, airborne hyperspectral imagery and multispectral satellite data to assess salt cedar populations prior to and following beetle release, and to follow beetle defoliation patterns from the original release sites across wide areas of impact. The coupling of colour and texture analysis was first used to identify, classify and map invasive $T$. parviflora during spring bloom, along a 50 -mile $(80-\mathrm{km})$ segment of Cache Creek in central CA, with an estimated 90\% accuracy (Ge et al., 2006).

An ongoing effort is further evaluating the use of hyperspectral imagery during mid-summer to identify vegetative salt cedar (without blooms) interspersed with other background native vegetation in this and other infested areas. Additional use of hyperspectral image assessment and GIS mapping has allowed biological control specialists to track and evaluate beetle performance at many pilot release sites where the beetles have spread across thousands of acres. A combination of aerial and ground sampling has clearly documented the success and safety of this project in multiple study areas. Now, however, due to the magnitude of the impact, aerial or satellite reconnaissance seems to be the only practical method of assessing the full impact, as tens of thousands of hectares have now been positively impacted by this AWPS programme.

Based on field results of the AWPM programme (documented primarily with remote sensing assessments), several state and federal agencies are highly enthusiastic about AWPM based on biological control, and have initiated efforts to use this technology over even yet wider areas. Thus remote sensing is expected to play a major role in the continued assessment of this beneficial invasive species management project.

Here, we will present remote sensing results from only a few of over a dozen specific research sites examined. Examples have been provided to cover the many different methods that have been used, alongside detailed assessments of aerial photography from Cache Greek, CA of salt cedar density and hyperspectral imagery from Lovelock and Schurz, NV to demonstrate beetle establishment, spread and defoliation impact on salt cedar populations.

However, these three types of remote sensing technology, along with videography and satellite imagery, have been used to assess salt cedar infestations and biological control impacts at most of our research locations in all of the states where the salt cedar leaf beetle has been released. Individual approaches varied at each site, depending upon the local biological situation and the personnel and equipment available in each area to conduct the work (see Carruthers et al., 2005). 
Aerial photography

Cache Creek is a small river that is located north and west of Woodland, CA $\left(38^{\circ} 40^{\prime} 02^{\prime \prime} \mathrm{N}\right.$ latitude and $128^{\circ} 45^{\prime} 30^{\prime \prime} \mathrm{W}$ longitude), and is the location of one of our Cretian beetle release sites. The stream course is highly infested with $T$. parviflora intermixed with a diverse combination of native flora, including many species of willows, cottonwood and other common riparian plant species (see Plate lc). This area is also infested with other exotic plant species of interest to our research team, including Arundo donax, Lepidium latifolium and Centaurea solstitialis, which are also being assessed using remote sensing. Cache Creek is of primary interest to us, as T. parviflora blooms in distinctive purplish-red blossoms (see Plate 6a) early in the spring prior to leaf-out of salt cedar and most other riparian vegetation. Therefore, this salt cedar is easily identified visually on the ground and from the air (see Plate 6b), making it possible for us to separate it from other vegetation at this time of the year.

During mid-season, however, it is difficult to separate $T$. parviflora from other green vegetation, as the plants are often intertwined and hard to see due to visual barriers caused by adjacent plant canopies. This area was chosen as one of our primary study sites because an extensive historical record of aerial photography exists for this location and thus provided a means of assessing salt cedar expansion through time. Currently, the salt cedar infestation on Cache Creek runs along approximately $80 \mathrm{~km}$ of river channel, much of which is hard to access on the ground, and is thus very difficult to map and manage. The use of remote sensing to assess and develop comprehensive distributional maps did allow local land managers to implement salt cedar removal, and allowed our team to better assess biological control impacts.

A total of 42 natural colour aerial photographs was taken, at a scale of 1:12,000, along Cache Creek in April 2002. At the time of photography, the salt cedar was in full bloom and was purplish-red in colour, making them distinctive from other associated riparian vegetation and the physical background in the study area (see Plate 6b). For analysis, the photographs were scanned at a l-foot resolution (1000 dpi) in full colour using three (blue, green and red) channels. Once processed for analysis, images were orthorectified and georeferenced to $1 \mathrm{~m}$ resolution digital orthoquads from USGS, using a second-order polynomial function. Each individual digital image was then evaluated for salt cedar, classified and then mosaiced to provide an areawide map of the salt cedar infestation.

Based on the colour similarity and relationships between various types of native vegetation and the invasive species, vegetation was initially divided into eight types: T. parviflora, evergreen trees, non-evergreen trees, shrubs, crops, bare fields (including agriculture and rangeland), water bodies (including wetlands) and rocks and roads. Colour patterns alone were not adequate to separate and classify the salt cedar from the other categories of habitat, and thus more complex methods of analysis were required. To distinguish salt cedar from associated vegetation and background required the combined use of colour and texture analysis to provide an adequate measure of salt cedar density (see Ge et al., 2006).

Since colour alone did not accurately separate salt cedar from the surrounding habitats (even though it was easily recognizable using the human eye due to largescale pattern recognition), more complex pattern recognition and texture analysis was used as an added component in the analysis. Using this approach, the overall average separability of salt cedar from other habitat types was significantly improved 
and habitat classification errors were minimized, with vegetation covers comparing reasonably to actual observed plant distributions (see Plate 6c).

Comparisons made between this automated salt cedar recognition process from the photographs resulted in a classification providing $90 \%$ accuracy through actual field validation (Ge et al., 2006). These classified images were then mosaiced across the study area in order to provide comprehensive infestation maps and to estimate the invasive salt cedar cover in a $40-\mathrm{km}$ test area of the Cache Creek drainage. The total area of salt cedar infestation for this single $40-\mathrm{km}$ section of stream was estimated at $3.98 \mathrm{~km}^{2}$. These maps (see Plate $6 \mathrm{~d}$ ) are now being used by local land managers in their salt cedar control programmes and as a basis for comparison against more detailed hyperspectral analyses being conducted.

Plate 7 shows aerial imagery from our Cache Creek test site, along with actual ground-based counts of adult beetle populations showing the exponentially increasing beetle population density. These data were collected across the study area as depicted on the GIS map showing the impacted trees on the ground. A further time sequence of remote sensed data collected via Quickbird satellite using multispectral imagery (scheduled but not collected) will provide a time series of defoliation events over the next few years that should allow more accurate and widespread assessment of beetle dispersion and impact, salt cedar decline and the beneficial response of native vegetation in the area.

\section{Hyperspectral remote sensing to assess beetle density and impact}

To best demonstrate the use of remote sensing for assessment of beetle defoliation and impact, we concentrated on the use of hyperspectral imagery that was collected at multiple insect releases sites, including our test area in Lovelock, Nevada $\left(40^{\circ} 1^{\prime} 20^{\prime \prime} \mathrm{N}\right.$ latitude and $118^{\circ} 31^{\prime} 24^{\prime \prime} \mathrm{W}$ longitude). The Lovelock site is adjacent to the Lovelock and Oreana Valleys that are along the Humboldt River, just upstream from the Humboldt Sink. The Lovelock Valley is one of Nevada's primary agricultural areas, where lucerne is grown mainly for seed production.

Salt cedar heavily infests the Humboldt River and side irrigation channels in this area, where salt cedar extends upstream for approximately $166 \mathrm{~km}$. Salt cedar is especially damaging in this drainage, as it both reduces available water for agriculture and blocks channel flow during times of heavy runoff. Local agricultural producers have been fighting salt cedar all along the Humboldt River Valley for the past two decades, and have been losing the battle. Salt cedar leaf beetle releases in this area have been extremely successful (see Plates 4 and 5). The beetles have highly defoliated the salt cedar and have spread $>150 \mathrm{~km}$ from the release site over the past 5 years. In fact, due to the extensive dispersal and impact of the AWPM programme, beetle impact can now only easily be evaluated using aerial or satellite reconnaissance.

Hyperspectal aerial imagery was acquired over study areas using a CASI II imaging system on 2 July 2002, 29 August 2002, 18 July and 10 September 2003 and 18 September 2004. In the last two seasons (2005 and 2006), the area of impact was so large that it was only practical to use satellite imagery to assess the area of defoliation. Thus, Quickbird satellite imagery was acquired to assess beetle damage. To our 
knowledge, this is the only biological control programme that has ever used such technology to assess natural enemy spread and programme impact.

The CASI II is a line scanner, covering $545 \mathrm{~nm}$, between 400 and $1000 \mathrm{~nm}$, that recorded the calibrated radiance values that were used in this analysis. Spectral and spatial coverage were changed over the course of the study to best accommodate biological control damage assessment, but ranged between 1 and $2 \mathrm{~m}$ pixel resolutions on the ground. Both were adequate to assess beetle defoliation; however, as the programme increased in impact we had to decrease resolution to increase the area being covered to circumscribe the defoliation within the available time of data collection. Spectral resolution also varied between years, ranging between 32 and 48 bins $(400-1000 \mathrm{~nm})$ and covering between 10 and approximately 3170 ha, as necessary, to encompass the target area where beetles were active.

Geographic coordinates for each line of the CASI images were recorded in real time using a differential global positioning system (GIS) coupled with the system's inertial momentum unit. Image to image registration was performed to compensate for much of the spatial registration error that confounds temporal difference analysis. Images were then transformed to the Normalized Difference Vegetation Index (NDVI), and change detection analysis was used to determine differences collected over the period of study. Areas showing change were photo-interpreted and matched to ground observations on beetle occurrence to ensure that the change was the result of D. elongata feeding damage to salt cedar. All areas of salt cedar that had been defoliated were subsequently masked (in yellow) as a region of interest (ROI), and the impacted canopy area was quantified (in ha, see Plate 8).

Analysis for the 2 July 2002 imagery indicated a total imaged area of approximately 1697 ha, which was the most infested with monotypic salt cedar (see Plate 8a). During this sample period we could see no visible salt cedar damage. Significant defoliation of salt cedar was first identified by ground crews, just prior to the August 2002 flight, where the damaged plants clearly show in the infrared area of the spectra. Change detection between the July 2002 and August 2002 image pairs (see Plate 8a and $\mathrm{b}$, respectively) indicated that the biological control agents had defoliated approximately 0.35 ha (canopy area and $c .1$ ha in ground area) over the 2-month period.

By July of 2003 the total amount of salt cedar defoliated had increased to 3.4 ha of canopy ( 4.3 ha of ground area, see Plate $8 \mathrm{c}$ ) and, in the interval between the 18 July 2003 and 10 September 2003 flights (62 days), D. elongata had defoliated approximately 76.7 ha of canopy (c. 200 ha of ground area, see Plate 8). Between the initial flight of 2 July 2002 and the 10 September 2003 flight, the defoliation had progressed approximately $2.8 \mathrm{~km}$ from the original release site and produced an impact span of approximately $5.2 \mathrm{~km}$ (south-west to north-east). The beetles themselves had actually spread much further along the Humboldt drainage, but defoliation levels were not detectable at these low densities.

By 2004 the area of impact had grown so large (see Plate 9) that it could no longer be easily assessed using fixed-winged aircraft, and thus satellite imagery was used to assess beetle spread and impact. Although we are still working out the details of this assessment technology, we have estimated that every salt cedar plant within a 27,500 ha area around the Lovelock release site was highly defoliated by the beetle. Unfortunately, we do not have pre-release imagery on this same scale, so we are not able to conduct a more comprehensive change detection analysis. However, totally 
defoliated and dying salt cedar plants are readily identifiable in the Quickbird imagery (see Plate 10) at the centre of the original release site.

Results indicate an exponential rate of beetle population growth, spread and salt cedar defoliation at each of our successful release sites. A total of nine other sites were monitored using similar techniques to those used in Lovelock, NV (not reported here). Many of these other areas have more typical riparian vegetation, with a mixture of salt cedar and other plants. Defoliation rates in these areas indicate that impacts to salt cedar are somewhat slower across most of the plant's range, but that insect establishment has occurred, that the beetle populations are building and that salt cedar is being negatively impacted at almost all of the test locations (see DeLoach et al., 2007a).

\section{Unintended negative and positive consequences of the AWPM programme}

The largest unexpected consequence of this biologically based AWPM programme was that its effectiveness and spread proceeded almost too quickly. The establishment of beetles at most of our test sites was rapid, with exponential increases in beetle numbers and tremendous spread of the agent throughout areas adjacent to the targeted watersheds. In some areas the insects and associated defoliation has literally spread hundreds of kilometres and impacted tens of thousands of hectares of salt cedar within 6 years following a one-time point release of beetles. The spread and impact of the beetle highly surpassed our expectations and overwhelmed our short-term monitoring capabilities.

However, no unintended negative impacts have been seen throughout the course of this programme, only extensive and beneficial defoliation of salt cedar. We believe that this is primarily due to the extensive safety and efficacy testing that was conducted in advance of the release of this insect into the environment. This rapid impact has been a very positive attribute of the AWPM programme using $D$. elongata; however, its rapid impact means that land managers now need quickly to follow up with activities to keep other invasive species from filling opening niches.

Researchers and implementation teams, however, are working hard to conduct accelerated revegetation research and implementation efforts in preparation for the wide areas that may soon have significantly declining populations of salt cedar (Lair and Wynn, 2002). The consequences of such declines are overwhelmingly positive, however, long-term monitoring and assessment by land management agencies, such as the Bureau of Land Management and the Bureau of Reclamation, are now extremely important. USDA-APHIS as the lead organization in the areawide implementation of this effort must directly interface with both public and private land and waterway managers to continually assess and take action where needed. Such activities have been planned and are now being implemented across release areas to identify and quantify environmental damage if it occurs.

\section{Economic evaluation of the AWPM programme}

The economic benefits of the AWPM effort to control salt cedar are potentially very great although not yet quantified, as several questions remain as to the natural 
balance that will be achieved between the leaf beetle and the salt cedar populations across different parts of the USA. Clearly, different evaluation metrics are appropriate as we move from totally environmental values to those involving human uses of land and water resources for agriculture and metropolitan uses of water. Both the short-term impact of AWPM using biological control and its long-term sustainability will need to be accounted for in any such assessment. Economists from the University of California Davis have been contracted to conduct such an assessment (Carruthers et al., 2000), but longer-term impact assessments are required prior to their analysis having any real meaning.

Clearly, however, now that the research and developmental stages of the salt cedar AWPM programme using D. elongata have been developed, implementation is very inexpensive and requires only a minimum of effort to establish beetles, develop nursery and release sites to multiple beetle numbers, organize and implement redistribution mechanisms and deploy resources to conduct follow-up monitoring as needed to assess and enact revegetation efforts.

\section{Prospects for the long-term sustainability of the AWPM programme}

The prospect for long-term sustainability of this programme is very high, as it has been in many similar biological programmes for control of weeds over the years. However, it is unknown what the long-term future actually holds for the dynamic interactions between salt cedar and $D$. elongata. Currently, all field populations of this beetle seem to be free of host-specific natural enemies, as those were removed from this insect through the quarantine screening process. Such natural enemies of $D$. elongata work to suppress its population in Eurasia, as do some generalist predators both in its homeland, and now in its introduced range. Parasitism in Eurasia is thought to limit populations, and thus defoliation in the countries of origin does not reach the levels noted in North America.

However, since tachinid parasites of other similar insects - including the elm leaf beetle and its introduced tachinid parasite from China - exist in areas where salt cedar leaf beetles will eventually spread it may be that, once exposed to these natural enemies, $D$. elongata will be negatively impacted. Such natural enemies would be expected to reduce its population vigour and salt cedar suppression capabilities. Likewise, other more specific natural enemies, such as other parasites and pathogens, might also become adapted to use $D$. elongata, with similar negative consequences.

The effects that meso-level spatial dynamics of this system may have upon the interaction of salt cedar and the leaf beetle are also unknown. In China and other areas of origin, significantly lower densities of both the plant and this insect exist. Heavy defoliation does occur, but insects seem to change geographical locations between years, allowing the salt cedar to recover between defoliation events. In this way, there is always some non-affected salt cedar available to sustain the relationship. In areas where we have had dramatic defoliation results no such plant escape has yet been observed to occur, as $D$. elongata populations reach very high levels due to little or no top-down population regulation.

Plant availability as a food source (bottom-up regulation), therefore, is the dominant force controlling insect numbers. Such an undamped system may actually cause 
highly cyclic population dynamics and unstable behaviour in the longer term. Clearly, massive die-offs and localized extinction of beetles at some of our research sites suggests that this may be one potential outcome. A solution to this problem could be to introduce a second control insect that may dampen the population fluctuations. Alternatively, very low beetle numbers could be reintroduced (naturally or with our help) to re-establish a dominant force in controlling salt cedar growth and development. In reality, only time will prove the actual sustainability of this programme (with or without human intervention), and we watch with great interest.

\section{Summary and Future Direction}

\section{Expectations from control and future directions}

In the short term, we expect AWPM using biological control to reduce salt cedar over a period of 3-5 years and permanently to reduce the abundance - over many years - to below the economic or environmental thresholds of damage. We expect that both the salt cedar and beetles will remain at low fluctuating population levels but nearly always be present in the local environment, where a new ecological balance will be maintained. This is the situation that we expect under the variable and diverse habitats that we see all across the western USA; however, many different local outcomes are to be expected. It is actually very likely that we will need to develop and use additional natural enemies of salt cedar in areas where $D$. elongata does not adequately control this pest plant due to a combination of environmental or human factors. Several such insects have already been investigated overseas in case they are needed later in this programme (Jashenko and Mityaev, 2007).

Under the conditions that we now see, we expect the native plant communities to re-establish naturally in most areas where depth to water table and soil salinity are not too great. This should improve wildlife habitat and allow the recovery of many species of birds and fish, and of some mammals and reptiles, including several threatened and endangered species. Control of salt cedar is expected to increase the amount and quality of water available for irrigated agriculture, and municipal and environmental use, and to help fulfil the water rights agreements between states and between the USA and Mexico. Control also is expected to increase recreational usage of parks and wildland areas, to reduce wildfires and to allow the gradual reduction of salinity levels of surface soils in presently infested areas.

Large-scale revegetation projects are currently under development by the USDI Bureau of Reclamation for areas where natural revegetation may be insufficient. We expect that this will be needed in some areas of AZ, CA and NM. Thus, we feel that results to date indicate that the programme of AWPM of salt cedar using biological control has a high probability of providing good control of salt cedar over much of the infested area of the USA. Salt cedar has also invaded large areas in northern Mexico; the US programme easily could be extended into Mexico at very low cost, through the cooperation of Mexican scientists. Approval of the Mexican government, natural area managers and authorities was granted in the spring of 2007, and 
plans are now being made to begin testing of this programme at sites along the Rio Grande, in both Texas and Mexico.

We will continue to work to assess and improve the AWPM of salt cedar using biological control as the keystone method of control. In doing so, we will both monitor and assess the situation and work with implementation agencies such as USDA-APHIS and several state Departments of Agriculture, university scientists, private groups, Native Americans and other groups to make and improve action programmes using $D$. elongata. Also, several other potential biological control agents of salt cedar are being investigated and developed by our overseas cooperators. These natural enemies may be necessary for use in fringe climatic areas when $D$. elongata beetles may not provide sufficient control or where predators may limit control, or where their release may not be allowed. Additionally, we will seek natural enemies for other weeds of importance to our customers and cooperators that work for the protection of American agriculture and the environment.

\section{References}

BASF (2004) Arsenal Herbicide, Specimen Label, NVA 2004- 04-104-0185. BASF Corporation, Agricultural Products, Triangle Park, North Carolina.

Baum, B.R. (1967) Introduced and naturalized tamarisks in the United States and Canada (Tamaricaceae). Baileya 15, 19-25.

Baum, B.R. (1978) The Genus Tamarix. Israel Academy of Sciences and Humanities, Jerusalem.

Bean, D.W., Dudley, T.L. and Keller, J.C. (2007a) Seasonal timing of diapause induction limits the effective range of Diorhabda elongata deserticola (Coleoptera: Chrysomelidae) as a biological control agent for tamarisk (Tamarix spp.). Environmental Entomology 36, 15-25.

Bean, D.W., Wang, T., Bartelt, R.J. and Zilkowski, B.W. (2007b) Diapause in the leaf beetle Diorhabda elongata (Coleoptera: Chrysomelidae), a biological control agent for tamarisk (Tamarix spp.). Environmental Entomology 36, 531-540.

Brown, F.B., Ruffner, G. Johnson, R., Horton, J. and Franson, J. (1989) Economic Analysis of Harmful and Beneficial Aspects of Saltcedar. Final report to USDI Bureau of Reclamation, Lower Colorado Region, Boulder City, Nevada. Prepared by Great Western Research, Inc., Mesa, Arizona, 261 pp.

Carruthers, R.I. (2003) Invasive species research in the USDA Agricultural Research Service. Pest Management Science 59, 827-834.

Carruthers, R.I. (2004) Biological control of invasive species, a personal perspective. Conservation Biology 18, 54 57.

Carruthers, R., Spencer, D., DeLoach, J., D'Antonio, C., Dudley, T., Kazmer, D. and Knutson, A. (2000) Biologically-based Control for the Area-wide Management of Exotic and Invasive Weeds. USDA-GSREES-IFAFS Grant, Assistance Transaction Number 1408536, Washington, DC.

Carruthers, R.I., Anderson, G., DeLoach, C.J., Knight, J.B., Ge, S. and Pong, P. (2005) Monitoring saltcedar biological control impact. Proceedings Monitoring Science and Technology Symposium, US Forest Service, RMRS P-37CD, Fort Collins, Colorado.

Carruthers, R.I., Herr, J.C., Knight, J. and DeLoach, C.J. (2006) A brief overview of the biological control of salt cedar. In: Hoddle, M. and Johnson, M. (eds) Proceedings Fifth California Conference on Biological Control, University of California, Riverside, California, pp. 71-77. 
Carruthers, R.I., Herr, J.C. and DeLoach, C.J. (2007) An overview of the biological control of saltcedar. Proceedings of the Califormia Weed Science Society. 59 <In press>.

Cossé, A.A., Bartelt, R.J., Zilkowski, B.W., Bean, D.W. and Petroski, R.J. (2005) The aggregation pheromone of Diorhabda elongata, a biological control agent of saltcedar (Tamarix spp.): identification of two behaviourally active components. Fournal of Chemical Ecology 31, $657-670$.

Crins, W.L. (1989) The Tamaricaceae in the southeastern United States. Fournal of Arnold Arboretum 70, 403-425.

DeLoach, C.J. (1991) Saltcedar, an Exotic Weed of Western North American Riparian Areas: a Review of its Taxonomy, Biology, Harmful and Beneficial Values, and its Potential for Biological Control. Final report, USDI Bureau of Reclamation, Lower Colorado Region, Boulder City, Nevada, 433 pp.

DeLoach, C.J. and Gould, J.E. (1998) Biological Control of Exotic, Invading Saltcedar (Tamarix spp.) by the Introduction of Tamarix - Specific Control Insects from Eurasia. Research proposal to US Fish and Wildlife Service, 28 August 1998. 45 pp.

DeLoach, C.J. and Tracy, J.L. (1997) Effects of Biological Control of Saltcedar (Tamarix ramosissima) on Endangered Species: Draft Biological Assessment, 17 October 1997. USDA/ARS, Temple, Texas, 524 pp. + appendices.

DeLoach, C.J., Gerling, D., Fornasari, L., Sobhian, R., Myartseva, S., Mityaev, I.D., Lu, Q.G., Tracy, J.L., Wang, R., Wang, J.F., Kirk, A., Pemberton, R.W., Chikatunov, V., Jashenko, R.V.,Johnson, J.E., Zeng, H., Jiang, S.L., Liu, M.T., Liu, A.P. and Cisneroz, J. (1996) Biological control programme against saltcedar (Tamarix spp.) in the United States of America: progress and problems. In: Moran, V.C. and Hoffmann, J.H. (eds) Proceedings of the IX International Symposium on the Biological Control of Weeds, University of Cape Town, South Africa, pp. 253-260.

DeLoach, C.J., Carruthers, R.I., Lovich, J.E., Dudley, T.L. and Smith, S.D. (2000) Ecological interactions in the biological control of saltcedar (Tamarix spp.) in the United States: toward a new understanding. In: Spencer, N.R. (ed.) Proceedings of the XInternational Symposium on Biological Control of Weeds, Montana State University, Bozeman, Montana, pp. 819-873.

DeLoach, C.J., Lewis, P.A., Herr, J.G., Carruthers, R.I., Tracy, J.L. and Johnson, J. (2003) Host specificity of the leaf beetle, Diorhabda elongata deserticola (Coleoptera: Chrysomelidae) from Asia, a biological control agent for saltcedars (Tamarix: Tamaricaceae) in the western United States. Biological Control 27, 117-147.

DeLoach, G.J., Carruthers, R.I., Dudley, T.L., Eberts, D., Kazmer, D.J., Knutson, A.E., Bean, D.W., Knight, J., Lewis, P.A., Milbrath, L.R., Tracy, J.L., Tomic-Carruthers, N., Herr, J.C., Abbott, G., Prestwich, S., Harruff, G., Everitt, J.H., Thompson, D.C., Mityaev, I., Jashenko, R., Li, B., Sobhian, R., Kirk, A., Robbins, T.O. and Delfosse, E.S. (2004) First results for control of salt cedar (Tamarix spp.) in the open field in the western United States. In: Cullen, J.M., Briese, D.T., Kriticos, D.J., Lonsdale, W.M., Morin, L. and Scott, J.K. (eds) Proceedings of the XI International Symposium on Biological Control of Weeds. CSIRO Entomology, Canberra, Australia, pp. 505-513.

DeLoach, C.J., Knutson, A.E., Thompson, D.C. and Nibling F. (2005) Saltcedar Biological Control Consortium: Texas, New Mexico, Mexico Section, First (Organizational) Meeting: Minutes, Reviewes of Research and Resource Guide, 29-30 March 2005, El Paso, Texas, 103 pp. (http://bc4weeds.tamu.edu/weeds/rangeland/salt cedar-bcc-2005.pdf).

DeLoach, C.J., Milbrath, L.R., Carruthers, R.I., Knutson, A.E., Nibling, F., Eberts, D., Thompson, D.G., Kazmer, D.J., Dudley, T.E., Bean, D.W. and Knight, J.B. (2005) Overview of saltcedar biological control. Proceedings Monitoring Science and Technology Symposium, US Forest Service, RMRS P-37CD, Fort Collins, Ciolorado.

DeLoach, C. Jack, Knutson, A.E., Moran, P., Thompson, D.C., Everitt, J.H., Eberts, D., Michels, J., Lewis, P.A., Milbrath, L.R., Herr, J.C., Carruthers, R.I., Sanabria, J., 
Muegge, M., Richman, D., Tracy, J.L., Robbins, T.O., Hudgeons, J., Carney, V., Gardner, K., Fain, T., Donet, M., Jashenko, R., Li, B., Sobhian, R., Kirk, A., Mityaev, I., McMurry, M., Nibling, F., Diaz Soltero, H. and Delfosse, E.S. (2007a) Research and initial success on biological control of saltcedar in the United States, with emphasis on Texas and New Mexico. In: Proceedings of the Sixth Symposium on the Natural Resources of the Chihuahuan Desert, 15-16 October 2007, Sul Ross State University, Alpine, Texas. (In press).

DeLoach, C.J., Moran, P.J., Knutson, A.E., Thompson, D.C., Carruthers, R.I., Michels, J., Muegge, M., Eberts, D., Randall, C., Everitt, J E., O'Meara, S. and Sanabria, J. (2007b) Beginning success of biological control of saltcedars (Tamarix spp.) in the Southwestern United States. In: Proceedings of the Seventh International Symposium on Biological Control of Weeds, 22-27 April 2007, La Grande Motte, France. (In press).

Dudley, T.L. and Kazmer, D.J. (2005) Field assessment of the risk posed by Diorhabda elongata, a biocontrol agent for control of saltcedar (Tamarix spp.), to a nontarget plant, Frankenia salina. Biological Control 35, 265-275.

Everitt, B.L. (1980) Ecology of saltcedar - a plea for research. Environmental Geology 3, 77-84.

Everitt, H. and DeLoach, C.J. (1990) Remote sensing of Chinese tamarisk (Tamarix chinensis) and associated vegetation. Weed Science 38, 273-278.

Gaskin, J.F. and Schaal, B.A. (2003) Molecular phylogenetic investigation of US invasive Tamarix. Systematic Botany 28, 86-95.

Ge, S., Carruthers, R.I., Herrera, A.M. and Gong, P. (2006) Texture analysis for invasive Tamarix parviflora mapping using aerial photographs along Cache Creek, California. Environmental Monitoring and Assessment 114, 65-83.

Gerling, D. and Kugler, J. (1973) Evaluation of Enemies of Noxious Plants in Israel as Potential Agents for the Biological Control of Weeds, 1 Sept. 1970-31 Aug. 1973. Final Technical Report to USDA Agricultural Research Service, P.L. 480 (Project \#A10-ENT-36), Tel Aviv University, Department of Zoology, Tel Aviv, Israel. 197 pp.

Gould, J.R., Dudley, T.E. and White, L. (2000) Plan for Monitoring the Effects of Releasing the Saltcedar Leaf Beetle, Diorhabda elongata for Biological Control of Saltcedar. Prepared by the insect, vegetation and wildlife monitoring subcommittee of the Saltcedar Consortium, 29 March 2000, Temple, Texas 18 pp.

Habib, R. and Hassan, S.A. (1982) Insect Enemies Attacking Tamarisk, Tamarix spp., in Pakistan. Final Report, June 1975-June 1980, Commonwealth Institute of Biological Control, Pakistan Station, Rawalpindi, Pakistan, 138 pp.

Hart, C.R. (2004) The Pecos River Ecosystem Project Progress Report. Texas Cooperative Extension/ Texas A\&M University System and Texas Water Resources Institute, Annual Report for 2004, Section D, 10 pp. (http://pecosbasin.tamu.edu).

Hart, C.R. (2006) Pecos River Basin Assessment Programme. Annual Report to Texas State Soil and Water Conservation Board, under US Environmental Protection Agency, Clean Water Act Section 319, TSSWCB Project \# 04-11, December 2006. 17 pp.

Hart, C.R., Clayton, L. and Lee, B. (2000). Salt cedar control in Texas. In: Proceedings Rangeland Weed and Brush Management: the Next Millenium; Symposium and Workshop. Agricultural Experiment Station, College Station, Texas, p. 185-190.

Hart, C.R., White, L.D., McDonald, A. and Sheng, Z. (2005) Salt cedar control and water salvage on the Pecos River, Texas, 1999-2003. Foumal of Environmental Management 75, 399-409.

Herr, J.C., Carruthers, R.I., Bean, D.W., DeLoach, C.J., Kashefi, J. and Sanabria, J. (2007) Host preference between saltcedar (Tamarix spp.) and native non-target Frankenia spp. within the Diorhabda elongata species complex (Coleoptera: Chrysomelidae). Environmental Entomology (in press).

Herrera, A.M., Dahlsten, D., Tomic-Carruthers, N. and Carruthers, R.I. (2005) Estimating temperature-dependent developmental rates of Diorhabda elongata, a biological control agent of saltcedar. Environmental Entomology 34, 775-784. 
Jashenko, R.V. and Mityaev, I.D. (1999-2005) The Biocontrol of Tamarix Annual Reports. Tethys Scientific Society/Laboratory of Entomology, Institute of Zoology, Almaty, Kazakhstan (on file at USDA-ARS, Temple, Texas).

Kovalev, O.V. (1995) Co-evolution of the tamarisks (Tamaricaceae) and pest arthropods (Insecta; Arachnida: Acarina) with special reference to biological control prospects. Proceedings of the Zoological Institute, Russian Academy of Sciences at St Petersburg, Vol. 29. Pensoft Publishers, Moscow, 110 pp.

Lair, K.D. and Wynn, S.L. (2002) Research Proposal: Revegetation Strategies and Technology Development for Restoration of Xeric Tamarix Infestation Sites. Technical Memorandum No. 8220- 02-04, USDI Bur. Reclamation, Technical Service Center, Denver, Colorado, 48 pp.

Lewis, P.A., DeLoach, C.J., Herr, J.C., Dudley, T.L. and Carruthers, R.I. (2003a) Assessment of risk to native Frankenia shrubs from an Asian leaf beetle, Diorhabda elongata deserticola (Coleoptera: Chrysomelidae), introduced for biological control of saltcedars (Tamarix spp.) in the western United States. Biological Control 27, 148-166.

Lewis, P.A., DeLoach, C.J., Knutson, A.E., Tracy, J.L. and Robbins, T.O. (2003b). Biology of Diorhabda elongata deserticola (Coleoptera: Chrysomelidae), an Asian leaf beetle for biological control of saltcedars (Tamarix spp.) in the United States. Biological Control 27, 101-116.

Li, B. and Ming, L. (2001-2002) Annual Reports on Biological Control of Saltcedar, 2001-2002, Xinjiang Agricultural University, Unumqi, China; 2003-2005, Nanjiang Agricultural University, Nanjing, Jiangsu, China (on file at USDA-ARS, Temple, Texas).

Longland, W.S. and Dudley, T.E. (2007) Effects of a biological control agent on the use of saltcedar habitat by passerine birds. Restoration Ecology (in press).

Lovich, J.E. and de Gouvenain, R.C. (1998) Saltcedar invasion in desert wetlands of the southwestern United States: ecological and political implications. In: Majumdar, S.K., Miller, E.W. and Brenner, F.J. (eds) Ecology of Wetlands and Associated Systems, Pennsylvania Academy of Science, Easton, Pennsylvania, pp. 447-467.

Milbrath, L.R. and DeLoach, C.J. (2006a) Host specificity of different populations of the leaf beetle Diorhabda elongata (Coleoptera: Chrysomelidae), a biological control agent of salt cedar (Tamarix spp.). Biological Control 36, 32-48.

Milbrath, L.R. and DeLoach, C.J. (2006b) Acceptability and suitability of athel, Tamarix aphylla, to the leaf beetle, Diorhabda elongata (Coleoptera: Chrysomelidae), a biological control agent of salt cedar (Tamarix spp.). Environmental Entomology 35, 1379-1389.

Mityaev, I.D. (1958) A review of insect pests of Tamarix in the Balkhash-Alakul depression. Trudy Inst. Zool. Akad. Nauk. Kazakh. SSR 8, 74-97 [in Russian].

Mityaev, I.D. and Jashenko, R.V. (2007) Insects Damaging Tamarisk in Southeastern Kazakhstan. Tethys Scientific Society, Almaty, Kazakhstan, 184 pp. [in Russian].

Pemberton, R.W. and Hoover, E.M. (1980) Insects Associated with Wild Plants in Europe and the Middle East: Biological Control of Weeds Surveys. Miscellaneous Publication No. 1382, USDA, Washington, DC.

Sala, A., Smith, S.D. and Devitt, D.A. (1996) Water used by Tamarix ramosissima and associated phreatophytes in a Mojave Desert floodplain. Ecological Applications 6, 888-898.

Shaforth, P.B., Cleverly, J.R., Dudley, T.L., Taylor, J.P., Van Riper III, G., Weeks, E.P. and Stuart,J.N. (2005) Control of Tamarix in the western United States: implications for water salvage, wildlife use, and riparian restoration. Environmental Management 35, 231-246.

Sisneros, D. (1991) Herbicide Analysis: Lower Colorado River Saltcedar Vegetation Management Study. Report R-91 - 96, Applied Sciences Research, USDI-Bureau of Reclamation, Denver, Colorado.

Smith, S.D., Devitt, D.A., Sala, A., Cleverly, J.R. and Busch, D.E. (1998) Water relations of riparian plants from warm desert regions. Wetlands 18, 687-696.

Stenquist, S.M. (2000) Saltcedar integrated weed management and the Endangered Species Act. In: Spencer, N.R. (ed.) Proceedings of the X International Symposia on Biological Control of Weeds, Montana State University, Bozeman, Montana, pp. 487--504. 
Thompson, D.A., Petersen, B.A., Bean, D.W. and Keller, J.C. (2007) Hybridization potential of salt cedar leaf beetle, Diorhabda elongata, ecotypes. In: Proceedings of the XII International Symposium on Biological Control of Weeds, 22-27 April 2007, La Grande Motte (Montpellier), France. (In press).

Zavaleta, E. (2000) The economic value of controlling an invasive shrub. Ambio 29, 462-467. 